Published in Continental Shelf Research Volume 30, Issue 8, 15 May 2010, Pages 934-9499.

(c) Elsevier Science Bv. DOI: 10.106/j.csr.2009.07.002

\title{
Sediment budget in the Lagoon of Venice, Italy
}

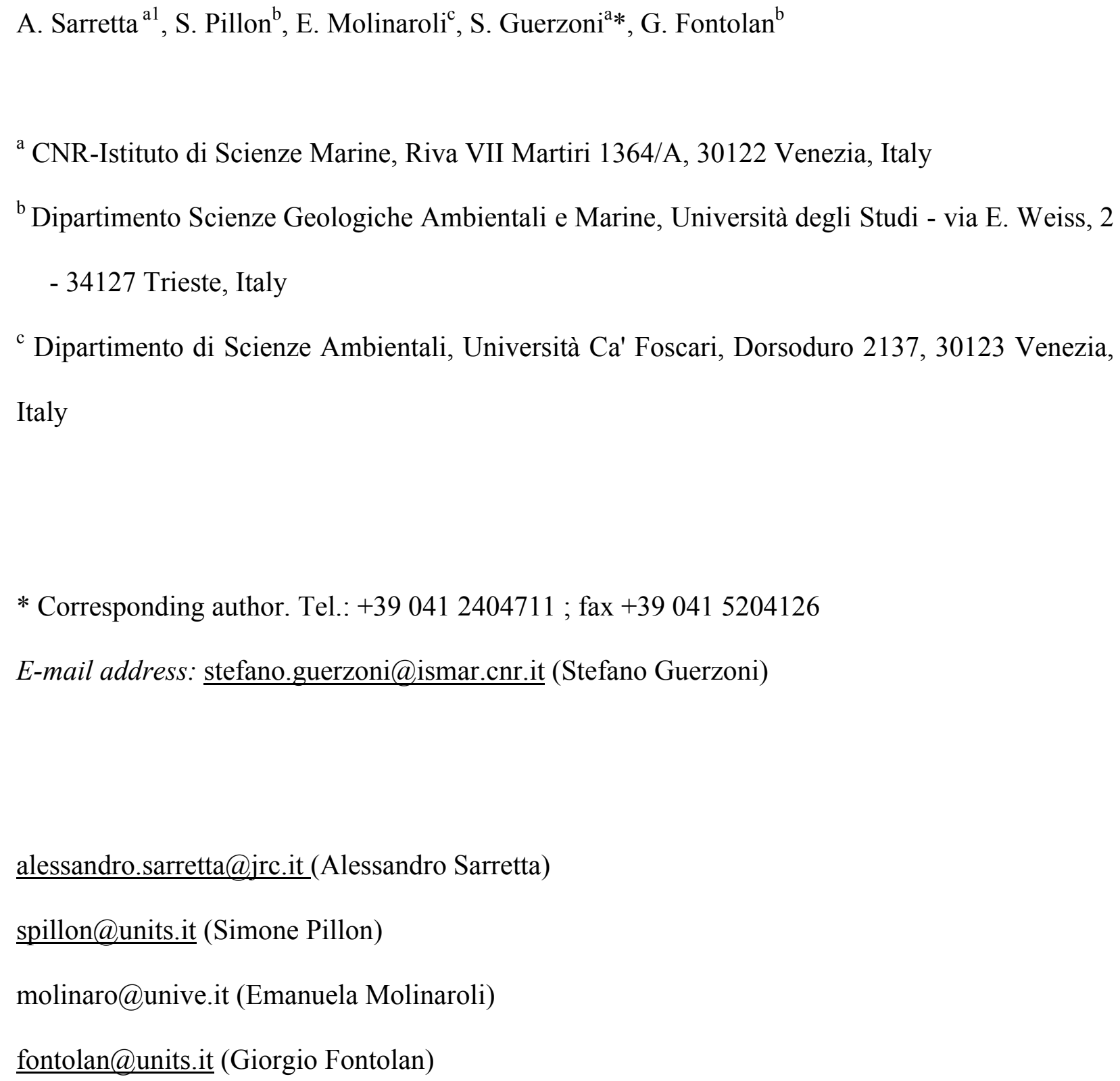

\section{Abstract}

A comparison of 1927, 1970 and 2002 bathymetric surveys in the Lagoon of Venice was used to reconstruct historical changes in sedimentation. A detailed GIS-based analysis of the charts

${ }^{1}$ Present address: European Commission - Joint Research Centre, Institute for Environment and Sustainability, Spatial Data Infrastructures Unit, Via Fermi - TP 262, I-21020 Ispra (VA), Italy. E-mail: alessandro.sarretta@jrc.it 
revealed the timing and pattern of geomorphic changes and allowed calculation of sediment

deposition and erosion for the entire lagoon and each of its four sub-basins: Treporti, Lido, Malamocco and Chioggia.

Two main developments are discernible from comparative observation of the areal distribution of the main elevation ranges: the diminution in area of the saltmarshes, which decreased by more than $50 \%$, from $68 \mathrm{~km}^{2}$ in 1927 to $32 \mathrm{~km}^{2}$ in 2002, and the progressive deepening of the lagoon, with a huge increase in the area of subtidal flats (between -0.75 and $-2.00 \mathrm{~m}$ depth), from 88 to $206 \mathrm{~km}^{2}$ during the same period.

Generally, the lagoon showed a clear-cut change in the most frequent depths (modal depth) from a value of $-0.62 \mathrm{~m}$ in 1927 to $-0.88 \mathrm{~m}$ in 2002 . The deepening of the lagoon affected mostly the lagoonal sub-basins south of the town of Venice, where modal depth increased from $-0.65 \mathrm{~m}$ to $1.12 \mathrm{~m}$ in Lido, from -0.64 to $-1.75 \mathrm{~m}$ in Malamocco and from $-0.39 \mathrm{~m}$ to $-0.88 \mathrm{~m}$ in Chioggia.

Large changes in lagoonal morphology were caused by human-induced subsidence, the dredging of navigation channels between 1927 and 1970, and intense natural erosion enhanced by sediment re-suspension due to Manila clam fishing between 1970 and 2002 . There was a net loss of about $110 \mathrm{Mm}^{3}$ of sediment from the lagoon, most of which $\left(73 \mathrm{Mm}^{3}\right.$, ca. $\left.70 \%\right)$ was in the earlier period. A significant amount was lost by dredging and direct disposal outside the system, either on land or at sea, and there was a net loss of $39 \mathrm{Mm}^{3}$ from the lagoon to the sea through the inlets, at an annual rate of $0.5 \mathrm{Mm}^{3}$.

Comparison of erosion rates in the two periods revealed an alarming acceleration, from a net sediment loss of $0.3 \mathrm{Mm}^{3} \mathrm{y}^{-1}$ in the period 1927-1970 to $0.8 \mathrm{Mm}^{3} \mathrm{y}^{-1}$ in 1970-2002. Deterioration caused a shift from a highly differentiated lagoon morphology in the 1930 s to a sediment-starved and subsidence-dominated structure in the 1970s, and from there to the high-energy and more open (bay-like) lagoon of today.

The results demonstrate the potential application of GIS to reconstruct the recent chronology of sediment distribution and to improve the understanding of the geomorphic processes shaping the 
seafloor, whilst providing an insight into the possible impacts of environmental changes induced by natural and anthropogenic forcing.

Keywords: bathymetry; morphological evolution; human-driven change; grain-size; lagoon of Venice, $45^{\circ} \mathrm{N}, 12^{\circ} \mathrm{E}$, coastal zoning 


\section{Introduction}

The saltmarshes of the Lagoon of Venice (LV) have experienced intense and varied human impacts that range from reclamation, waste disposal and livestock grazing to less obvious, more modern activities such as restoration efforts (Silliman et al. in press). Large expanses of tidal flats and open saltmarshes near cities were converted to port and industrial complexes, resulting in their permanent loss (Pinder and Witherick, 1990) and the disappearance of the ecosystem function they once performed.

The substantial changes that have taken place in the morphology of the Lagoon of Venice during its history result from a combination of natural processes, human activities, and sedimentological responses to such activities. Although knowledge of long-term trends in deposition and erosion are important for proper management of coastal ecosystems, it is difficult to gain this knowledge from brief field experiments. A long-term, large-scale perspective of the sediment system may be obtained, however, by analyzing a sequence of bathymetric surveys over a long time period (Jaffe et al., 2007). Understanding how lagoons have responded to past modification is necessary in order to prevent further degradation in response to future environmental pressures (Higgins et al., 2007), including invasive species (which fundamentally alter saltmarsh community structure) and the relatively unexplored and multifaceted effects of climate change (Bromberg Gedan et al., 2009).

This paper presents a history of bathymetry, deposition, erosion, and morphological changes (affecting saltmarshes and tidal flats) in the LV from 1927 to 2002, and relates them to changes in land-use and the main physical and sedimentological activities affecting the lagoon environment during the last few decades. The history was reconstructed using computer analysis (Longley et al., 2001) and hydrographic and topographic surveys conducted by the Venice Water Authority (Magistrato alle Acque di Venezia, MAV). This study is not the first to address bathymetric changes in the LV (MAV-CVN, 1999; MAV-CVN, 2004; Pillon et al., 2003 and Molinaroli et al.,2009) but it is the most comprehensive to date. Molinaroli et al. (2009) 
performed a precise division of the LV into four sub-basins using GIS-based techniques (Fig. 1):

Treporti (A), Lido (B), Malamocco (C) and Chioggia (D). The authors also demonstrated that the morphological and sedimentological variations between 1970 and 2002 were different in each sub-basin. In this paper we used their partitioning to follow the historic evolution of the bathymetry of the four sub-basins over more than 70 years, in order to construct two sediment budgets, one for the period 1927-1970 and another for 1970-2002.

\section{Study area and historical background}

The Lagoon of Venice is the largest lagoon in the Mediterranean. Like many other coastal areas around the world, it has been subject to transformations and intense anthropogenic pressure over the past few decades which have deeply modified the natural environment. The construction of breakwaters at the lagoon inlets during the period 1808-1927 and the dredging of lagoon channels for navigation (in 1926 and 1970) have had a significant impact on the lagoon's morphology (Guerzoni and Tagliapietra, 2006).

Tides in the area are semidiurnal, with neap, mean and spring tidal ranges of ca. 45, 65 and $100 \mathrm{~cm}$ respectively. Saltmarshes are areas within the lagoon above mean sea level, and tidal flats are the whole of the remainder of the lagoon below mean sea level except the channels. Tidal flats (mostly mudflats) are classified as either intertidal or subtidal flats, depending on whether they are above or below the mean low water spring tide value of $-0.50 \mathrm{~m}$.

Riverine sediment input into the lagoon has been almost completely eliminated, and the breakwaters constructed to defend the inlets have greatly reduced the input of coarse marine sediment into the lagoon (Day et al., 1998). As a consequence, erosion and subsidence, particularly during the last century, have caused a three-fold reduction in the area of saltmarshes in the Venice Lagoon to about $35 \mathrm{~km}^{2}$ at present. In the past 15 years or so, projects have been undertaken to arrest marsh loss and promote restoration (Scarton et al., 2000). 
Various events can be recognized as important activities affecting structures and processes in the

morpho-bathymetry of the LV between 1927 and 2002, and are listed in Table 1, chronologically subdivided in terms of the two periods considered for the bathymetric comparison (1927-1970 and 1970-2002). They are:

1. Saltmarsh destruction from 1927 to 1960 to reclaim land for the construction of the industrial zone (a total of $22 \mathrm{~km}^{2}$ ), together with Venice airport and urban development on the lagoon-side of the city of Mestre (S. Giuliano), the latter two occupying a further $5 \mathrm{~km}^{2}$;

2. modification of hydrodynamic conditions as a result of the dredging of the MalamoccoMarghera ship canal (the "Oil Canal"), in the central part of the lagoon in the 1960s. This work affected the first period of the study due to the disposal on land of the dredged material (more than $40 \mathrm{Mm}^{3}$ ), and the second period by influencing lagoon morphology (e.g. saltmarsh distribution and bathymetric features, such as texture, grain size, depth, and erosion rate) (Ravera, 2000);

3. increased nutrient and pollutant (trace metals and POPs) loads in the 1960s and 1970s, in relation to inputs from the industrial area and the catchment basin, and urban waste from the city of Venice (Cossu and De Fraja Frangipane, 1985; Donazzolo et al., 1982). These activities produced several million $\mathrm{m}^{3}$ of material with various levels of contamination; the new regulatory framework established by the Ministry of the Environment in the 1990s (Ministero Ambiente, 1993; Apitz et al., 2007) imposed strict guidelines regarding the disposal of this material;

4. dredging for maintenance purposes carried out in the last decade by the Water Management Authority of Venice and the Port Authority, amounting to an average of about 1 million $\mathrm{m}^{3} \mathrm{y}^{-1}$ of sediments (MAV/CVN 2004), which was dumped outside or re-used inside the lagoon; and 5. mechanical clam harvesting by local fishermen since the early 1990 s to exploit the newlyformed banks of Manila clams (Provincia di Venezia, 2000; Pranovi et al., 2004), an alien species, intentionally introduced into the lagoon in the middle of the 1980s for aquaculture and 
which subsequently became widespread throughout the lagoon (Cesari and Pellizzato, 1985; Pranovi et al., 2006).

\section{Materials and Methods}

\section{Insert Figure 1}

\subsection{Bathymetric datasets}

The bathymetric datasets used for assessing historical changes in the LV are derived from three maps published by the MAV after survey campaigns conducted in 1927, 1970 and 2002.

The " 1927 " bathymetric maps were published by the MAV in 1934 . They are the result of a detailed survey carried out between 1922 and 1933 (central year 1927) and consist of 134 maps on a scale of 1:5000. The survey was conducted by performing precise tacheometric measurements and manual soundings. A precise altimetric network covered the entire lagoon surface. These maps have recently been digitized by the Venice municipal Tide Forecast Centre as high resolution TIFs.

The "1970" bathymetric maps were published in 1971 by the MAV. They were the result of surveys carried out from 1968 to 1971 . Bathymetric data were collected by multiple sampling methods: echosounding, tacheometric measurements and stereophotogrammetric analysis.

The "2002 dataset was collected from the end of 1999 to June 2002, further data being collected in spring 2003. A "Multibeam" bathymetric acquisition system was used for the main channels (depth $>5 \mathrm{~m}$ ) and the three seaward inlets (Lido, Malamocco, Chioggia). For shallow waters and secondary channels (depth $<5 \mathrm{~m}$ ), a single-beam echo-sounder was used. At shallower depths near saltmarshes and on tidal flats, data are collected by the traditional topographic method (stadia rods coupled to a GPS). The distribution of natural and artificial saltmarshes was surveyed by stereo aerial photography. Digital data for both the 1970 and 2002 maps were provided by the MAV.

\subsection{Sea-level reference datum and adopted corrections}


Comparison of surveys and their related morpho-bathymetric maps requires consideration of the reference datum used during each survey. For a sediment budget calculation, vertical movement (of land and sea) also has to be considered, in order to distinguish actual from apparent sediment losses.

The datum used in the 1927 map is the National Altimetric Network Zero (NANZ), established in 1910 by the IGM (the Italian Military Geographical Institute) with reference to the tide gauge at Campo S. Stefano (CSS), Venice. The NANZ corresponds to the average of the high and low tides recorded from 1884 to 1909, assigned to the median year 1897 (Dorigo, 1961). In 1923 the reference tide gauge of Venice was transferred to Punta della Salute (PdS). Elevation differences between benchmarks associated with both CSS and PdS are negligible, in the order of 3-4 mm, thus within the tolerance errors of levelling between two geodetic elements.

The hydrographic maps of 1970 and 2002 both refer to the datum established in 1952 (and which is still in use), corresponding to the mean sea level recorded at Genoa in 1942 (IGM42). Altimetric measurements were carried out in 1968 in order to control and position the new datum with respect to the NANZ at Venice. Using the PdS benchmark as the reference control, the IGM42 datum was found to be $23.56 \mathrm{~cm}$ higher than the NANZ (Cavazzoni, 1977; Ferla et al., 2006). This value is a result of both the eustatism and subsidence, natural or human-induced (Gatto and Carbognin, 1981), which has occurred since the beginning of the last century.

Reference data and sea-level time series are shown in Fig. 2. Mean sea-level data are available for both Venice and Trieste; the latter is a tectonically stable maritime city located $115 \mathrm{~km}$ from Venice, on the eastern side of the northern Adriatic. A graphic indication of the subsidence which occurred in Venice during the examined period is given by the differing rates of apparent sea-level change in the two cities (Fig. 2b). It was about $10 \mathrm{~cm}$ greater in Venice than Trieste during the critical period 1927-70, when there was intensive water extraction from the deep aquifers underlying the former to supply industries centred on Marghera. According to Gatto and Carbognin (1981) the relative level of the land fell by a total of $23 \mathrm{~cm}$ over 100 years: ca. $3 \mathrm{~cm}$ 
are due to natural (geological background) subsidence, ca. $9 \mathrm{~cm}$ to anthropogenic subsidence and

$11 \mathrm{~cm}$ to the rise in mean sea-level. Mean sea level is still rising, with absolute values currently up to $27-28 \mathrm{~cm}$ above the NANZ.

Considering the above data and the values shown in the graph (Fig. 2), it is now possible to specify the correction to use when analysing topographic variations over time.

The differences between mean sea levels measured during, or immediately before, the period of survey and the reference datum were calculated for each map, using the long term sea-level time series (Fig. 2). The depth correction for the 1927 map, surveyed during 1922-33 (median year $=$ 1927) is $6 \mathrm{~cm}$, to compensate for the rise in mean sea level compared to the NANZ value (i.e., the relative sea level rise which occurred between 1897 and 1927). The average sea level measured during the period 1922-33 was adopted as the 1927 mean sea-level.

Analogously, considering the mean sea level for both the 1970 and 2002 charts as the mean sea level calculated over the 10 years before the last year of each survey, no correction is needed for either of the maps, since the reference datum (IGM42) is only $1.4 \mathrm{~cm}$ higher than the 1970 mean sea-level and approximately the same as the mean sea level in 2002.

Calculation of the sedimentary budget requires a more accurate knowledge of the depth values, in order to identify the "real" depth changes, i.e., those that are due to erosional or depositional processes. Thus, the lagoonal mass balance can be only obtained by eliminating vertical movements of both land and sea occurring between each pair of comparison maps. For the sediment budget 1927-70, the depth correction adopted is $23 \mathrm{~cm}$, as the approximation of the absolute difference between the IGM42 and NANZ levels $(23.56 \mathrm{~cm})$, measured at the reference PdS benchmark, which is the product of both eustatism and subsidence. Unfortunately, in this comparison it was not possible to use differential subsidence values for the individual sub-basins of the lagoon, since a precise topographic network for monitoring land displacement is available only for the more recent period. 
Given the use of the same reference datum and the small variations in sea level, the 1970-2002 mass balance was calculated from original elevation data corrected only for the differential subsidence occurring in the lagoon sub-basins during the time span, available from spatial data reported by Brambati et al. (2003) and Carbognin et al. (2004).

Insert Figure 2

\subsection{Sedimentology}

Sedimentological information contemporary with the bathymetric chart of 1927 is very scarce. The few papers from that time dealing with surficial sediment characteristics mainly focus on benthic communities (Vatova, 1940, 1949), and only a rough description of sand/mud ratios in a few sub-areas was reported. In contrast, two sampling campaigns performed in the 1970s and in 2000s provide us with much more information (Molinaroli et al., 2009). The samples from the first campaign were collected between 1976 and 1978 by the Sezione Geo-Mineralogica of Ca' Foscari University in Venice, when more than 200 sediment samples $(\sim 10 \mathrm{~cm}$ thick $)$ were collected with PVC pipes. Samples were collected from the lagoon floor, at water depths of between 0.1 and $2.4 \mathrm{~m}$. The second set of samples was collected in 2002 by the Institute of Marine Sciences of Venice when 140 bottom sediment samples ( $\sim 8 \mathrm{~cm}$ thick) were collected with a PVC pipe from the lagoon floor at depths of between 0.2 and $2.2 \mathrm{~m}$. Molinaroli et al. (2009) showed that in both cases samples were taken from over the complete lagoon with the exception of fish farms and reclaimed areas; the analytical procedures used for the two sampling campaigns were practically the same.

\subsection{GIS and spatial analysis}

\subsubsection{Map georeferencing and digitizing}

The three bathymetric datasets $(1927,1970,2002)$ were processed to produce three bathymetric models of the LV. Every step in the analysis was performed using the ESRI ArcGis and QGISGRASS environments. The datasets were of two types: the 1927 one was supplied in raster 
format maps (TIFs) by the Venice municipal Tide Forecast Centre, while the other two datasets (1970, 2002) were in ESRI shape format, as supplied by the MAV.

The 1927 TIFs were georeferenced using control points recognized on a digital map, the Technical Regional Map in Autocad format, nominal scale 1:5000, based on the Gauss-Boaga Projection (Italian National Coordinate System). Although the original coordinate system adopted in 1927 was different, because the national coordinate system was changed in 1952, a previous comparison between the 1927 and 1970 maps, performed by the same institution which had published them, stated that the difference was not relevant at the scale involved (Rusconi, 1987).

Once geo-referenced, the TIFs were mosaiced to check for overlap. Where the overlapping rasters did not match, a check for geo-referencing errors was performed.

The subsequent phase was the digitalization of the morphological features in the lagoon. The dataset included three different geometric types of object: points, polylines and polygons.

Points were used to represent spot elevation data, while polygons were used to contour the saltmarshes. Polylines were used as an aid in the process of building the surface.

\subsubsection{Bathymetric models}

To create the lagoon morphological models, a TIN (Triangulated Irregular Network) interpolation type was chosen, because it is precise (it maintains the original data at the sample points) and varies its precision in accordance with data density. The lagoon was subdivided into three morphological categories (saltmarshes, submarine areas and channels) using specific vector layers provided by the MAV. Each zone was interpolated individually, to avoid the problems associated with abrupt changes in slope. The TIN processed using the whole dataset experienced some interpolation problems, located at the transitions between the three categories. The interpolated surfaces did not respect the real transition between different morphologies, thus introducing errors of volume calculation. 
The three datasets cover different areas, that of 1927 having the widest coverage. This is because

the area of the lagoon open to tidal circulation varied during the period in question. Therefore an analysis mask was used to study the evolution on a common surface. The mask represents the open lagoon surface as it was in 1970 without the fish farming and unfinished reclamation areas. The analysis mask was supplied by the MAV. All three TINs were checked for interpolation errors, which were often caused by errors in the digitalization process. Those errors were of two types: positive-to-negative inversion and misplacement of data points, i.e. channel data points placed inside saltmarsh polygons. The datasets were thoroughly analyzed to find and correct these errors. Once the TINs were validated they were converted to Grids (ESRI raster format) with $10 \mathrm{~m}$ cells. The cell dimension was chosen to produce as detailed a representation of the models as possible while keeping the required processing power within manageable limits.

Rasters cannot represent vectorial models in detail, because the entities are quantized, and therefore limited to describing features bigger than the cell's dimensions. This means that the raster surface area is smaller than the TIN surface area, though the difference amounts to $0.1 \%$. This problem was particularly evident when the three rasters (saltmarshes, submarine areas and channels) were combined to build the lagoon model. The resulting raster presented "no-data" cells at the borders of the three original rasters. This problem was solved by a Map Algebra operation which assigned to these no-data cells a mean value calculated from the 8 adjacent cells. Although the same analysis mask was used, the three raster models had different total surface areas. The difference is small and amounts to $0.2 \%$ of the total lagoonal surface area. Analysis of the data points falling within the polygons of saltmarshes gave different mean elevations for each dataset: $0.24 \mathrm{~m}, 0.22 \mathrm{~m}$ and $0.30 \mathrm{~m}$ for the 1927, 1970 and 2002 surveys respectively. The elevation of the marshes was sampled with different methods in the three surveys. Despite being older, the 1927 survey turned out to be most accurate, because the marshes were surveyed with tacheometric methods whereas in the two more recent surveys the stereo photogrammetric method was applied. Several recent studies show that the North Adriatic 
vegetated marshes have a typical elevation of between 0.25 and $0.30 \mathrm{~m}$, comparable to the mean value of the 1927 survey (Favero et al., 1992; Albani et al., 2001; Bonometto, 2005; Silvestri et al., 2005; Marani et al.,2007). The elevation of the saltmarshes is important for the volumetric calculations. However, given the lack of consistency in the altimetric measuring techniques used in the three surveys, the saltmarshes were converted to rasters with a constant elevation equal to the mean value of the 1927 survey, i.e., $0.24 \mathrm{~m}$.

The three rasters were then reclassified to analyze the frequency distribution of the bathymetric categories. Fourteen classes were chosen following a classification used by Rusconi (1987) in his analysis of the 1927 and 1970 maps. To perform these analyses the three bathymetric maps were considered as "snapshots" of the lagoon at the time, so they were corrected only for differences between the sea-level reference datum used and the mean sea level at the time of the soundings. Only the 1927 map was corrected, by $6 \mathrm{~cm}$. To calculate volumetric changes, two difference rasters were produced by a MapAlgebra operation using the ArcGIS "Raster Calculator" tool. The bathymetric values of the 1927 grid were subtracted from the 1970 values and the values of the 1970 grid were subtracted from the 2002 values, generating two raster maps of depth differences with the same resolution as the input maps, enabling a detailed assessment of the morphological changes occurring during the last 75 years. The final maps were corrected for datum and subsidence for 1927 and only for subsidence in the period between 1970 and 2002 as calculated by Brambati et al. (2003).

\subsubsection{Geostatistics of sediment data}

The 1970 and 2002 sedimentological datasets consisted of two vectorial (point) layers containing 17 intervals of grain-size. An IDW (Inverse Distance Weighted) interpolation was executed for each interval, obtaining 34 grids with $10 \mathrm{~m}$ resolution cells, representing the spatial distribution of specific grain-size dimensions throughout the lagoon. Differences between the sedimentary maps of 2002 and 1970 were obtained by subtracting each 1970 map grid from its corresponding 2002 map grid. 


\section{Results and discussion}

\subsection{Morphological transformations}

The morphologies of the Lagoon of Venice in 1927, 1970 and 2002 are shown in Fig. 3. The morphology is typical of a coastal lagoon, where water exchanges with the sea occur through three main tidal inlets. A complex network of channels has developed in the lagoon with a main channel and reaching the inner lagoon through secondary and then higher order channels (creeks). Marshes are found mainly in the inner parts of the lagoon. A significant amount of sediment in the northern basin is the result of rapid settling of suspended particles in estuarine areas characterised by freshwater inputs from the Silone, Dese and Osellino rivers, which account for about $46 \%$ of the total riverine inputs of suspended matter to the lagoon (Zonta et al., 2001). A significant area of marsh have also formed by sedimentation along the edges of the channel network (i.e. levees), as a result of the abrupt morphological, and thus hydrodynamic, contrast between the channels and the adjacent tidal flats.

\section{Insert Figure 3}

Two main phenomena are easily discernible from Figure 3 and Table $2 \mathrm{a}, \mathrm{b}, \mathrm{c}$ : the diminution in area of the saltmarshes, which decreased by more than $50 \%$ from $68 \mathrm{~km}^{2}$ in 1927 to $32 \mathrm{~km}^{2}$ in 2002, and the progressive deepening of the lagoon, with an increase in the area of subtidal flats between -0.75 and $-2.00 \mathrm{~m}$ deep, from 88 to $206 \mathrm{~km}^{2}$, during the same period.

Evidence of transgression is seen in the enlargement of subtidal flats deeper than $-1.2 \mathrm{~m}$ (Fig. 3), which represent the remnant of the ancient depressions and ponds of the former Venetian alluvial plain, over which the early lagoon formed during the mid-Holocene highstand (Fontana et al., 2004). In 1927 these depressions had an area of up to $23 \mathrm{~km}^{2}$ and a mean depth of $-2.1 \mathrm{~m}$. By 1970, relative sea-level rise had caused this area to double in size, though the average depth fell to $-1.6 \mathrm{~m}$. This shallower mean depth is due to the contribution of ca. $22 \mathrm{~km}^{2}$ of flooded subtidal flats, formerly between $-1.00 \mathrm{~m}$ and $-1.25 \mathrm{~m}$. 
In 2002, the mean depth was still $1.6 \mathrm{~m}$, although the area of subtidal flats deeper than $-1.2 \mathrm{~m}$

was $105 \mathrm{~km}^{2}$. Since relative sea level did not change significantly between 1970 and 2002, this further doubling of the area of deep subtidal flats indicates erosion due to enhanced hydrodynamic forcing.

The deepening of the lagoon affected mainly the southern sub-basins $\mathrm{C}$ and $\mathrm{D}$, and only part of basin B, south of the town of Venice, as already shown by Molinaroli et al. (2009) for the 19702002 period. The distribution of area changes (losses and gains) of the different elevation categories within the lagoon (Table $2 \mathrm{~b}, \mathrm{c}$ ) and within each sub-basin was significantly different in the two periods. During 1927-70, the greatest area reductions were seen in the saltmarshes and intertidal flats. The area expansion of the other categories (below $-0.75 \mathrm{~m}$ ) is related to depth increases, as for the subtidal zones, while for the channels, to the effects of the large scale excavations carried out in the industrial area. Therefore $0.75 \mathrm{~m}$ is the fulcrum depth (i.e. the depth which separates negative from positive area changes) of the morphological adaptation of the lagoon to relative sea-level rise caused by the combined effects of eustatism and subsidence. The following period (1970-2002) saw the enhancement of erosion, leading to an expansion of subtidal flats below $-1 \mathrm{~m}$. In contrast, the categories affected by losses were mainly subtidal flats at a depth of between $-0.5 \mathrm{~m}$ and $-1 \mathrm{~m}$, the latter depth becoming the new fulcrum of morphological adaptation of the lagoon system.

For sub-basin C, erosion gave rise to an increase of $26.7 \mathrm{~km}^{2}$ in the area of subtidal flats below $1.5 \mathrm{~m}$, which is currently the greatest modal depth of the four sub-basins of the LV, and more than $75 \mathrm{~cm}$ deeper than the modal depth of the same sub-basin in 1927.

The frequency distribution of the areas as a function of elevation in 1927, 1970 and 2002, were calculated for the whole lagoon and for each of the sub-basins A to D (Fig. 4). The frequency curves of the three periods for the whole LV showed a clear shift in the mode from a value of $0.62 \mathrm{~m}$ in 1927 , to $-0.87 \mathrm{~m}$ in 1970 , and $-0.88 \mathrm{~m}$ in 2002 . A similar shift in bathymetry was observed by Fagherazzi et al. (2006) when comparing the 1901 and 2000 lagoonal morphologies 
of the southern lagoon. These authors showed that shallow tidal basins (such as the Lagoon of

Venice) are characterised by extensive tidal flats and saltmarshes that lie within specific ranges of elevations, between which intermediate elevations $( \pm 0.25 \mathrm{~m})$ are less frequent due to their inherent instability as a result of fetch (Fagherazzi et al., 2007). With high deposition rates such as those of 1901 - the most frequent tidal flat elevation was around $-0.50 \mathrm{~m}$, which tended to shift towards lower elevations when sediment availability was reduced (Fagherazzi et al., 2006; Marani et al., 2007).

Despite the difficulties of comparison between Fagherazzi et al. (2006) and the authors frequency analysis of lagoon elevations (since the studied surfaces are not coterminous), a modal elevation was also observed for the entire lagoon of ca. $0.6 \mathrm{~m}$ in 1927. The slight shift from the previous value of $-0.50 \mathrm{~m}$ during 1901 , may reflect reduced sediment input due to reclamation for the first industrial zone in the 1930s and the damming of rivers in the 1920s. The significant additional shift towards $-0.87 \mathrm{~m}$ by 1970 is related to several reclamations (the $2 \mathrm{nd}$ and $3 \mathrm{rd}$ industrial zones, airport and housing in Mestre), together with the dredging of sediment for the Malamocco-Marghera ship canal, which was mostly disposed of on land. The final shift towards the value of $\sim 0.90 \mathrm{~m}$ (seen in 2002) is not so evident as in the previous period, but looking at the evolution of the individual sub-basins, it coincides with the subtidal flat erosion phase proposed by Defina et al. (2007). According to these authors, in a "starved" lagoon the instability of the tidal flats inside basins with large open fetch will ultimately lead to a smooth horizontal bottom with increased depths of up to $2.0-2.5 \mathrm{~m}$. This is clearly seen in the Malamocco and Lido subbasins, where the modal depth is $1.75 \mathrm{~m}$ and $1.12 \mathrm{~m}$ respectively, both significantly deeper than 1970. This means that abrupt change has taken place since the large-scale submergence of the largest open basin of the lagoon, which caused increased erosion due to wave-induced currents during strong NE (Bora) wind events (Cavaleri, 1980; Fagherazzi et al., 2007).

By contrast, during the period 1927-1970, the mean depth in basin A changed by the same order as that of the relative sea-level rise. After 1970 no significant morphological changes occurred 
confirming that a complex and mature lagoon morphology inhibits the effect of wave-induced currents by Bora winds to cause erosion.

\section{Insert Table 2}

\section{Insert Figure 4}

\subsection{Historical deposition, stability and erosion}

The differences in bed elevation for the three data sets are presented in the form of erosion maps (Fig. 5) subdivided into four categories: (1) severe erosion (<-0.5 m difference), (2) moderate erosion (difference between -0.1 and $-0.5 \mathrm{~m}$ ), (3) stability and (4) deposition. Stability corresponds to the range $\pm 0.1 \mathrm{~m}$, and deposition corresponds to cells with deposition values greater than $0.1 \mathrm{~m}$.

\section{Insert Figure 5}

\subsubsection{Bathymetric chart comparison: $1927-1970$}

$15 \%$ of the lagoon is characterized by severe erosion, $29 \%$ by moderate erosion, $34 \%$ is stable and $22 \%$ is depositional (fig. 5). The areas affected by severe erosion are concentrated mostly in the channels, mainly the Malamocco-Marghera ship canal (the "Oil Canal") and the whole of the industrial area with its canals and docks, which were excavated in the late 1960s. The areas affected by moderate erosion are mostly tidal flats. Stable areas are evenly distributed across saltmarshes and tidal flats. Deposition is seen in many channels and on some intertidal flats.

The dominant factor driving morphological transformation in the 1927-1970 interval was subsidence, which had a significant human-induced component (c.f. 2.2 and 3.1). Most of the areas of severe erosion coincide with the Oil Canal, Vittorio Emanuele Canal and the industrial docks, from which about $40 \mathrm{Mm}^{3}$ of sediment was dredged. The other affected areas were the saltmarshes, which by 1970 had been reduced to about half the surface area they occupied in 1927, with a loss of $25 \mathrm{Mm}^{3}$. A common phenomenon throughout the lagoon was the erosion of the main channels while the secondary channels were characterised by deposition, with some of 
the material coming from the erosion of the nearby tidal flats and saltmarshes which suffered

moderate erosion. This process is mainly apparent in the open lagoon, especially in the Lido and Malamocco sub-basins (B and C), while in the more protected areas where saltmarshes prevail (the Treporti and western Malamocco sub-basins), the movements of sediment are more complex. In the lagoon as a whole, tidal flat erosion involved the movement of $66 \mathrm{Mm}^{3}$, of which $17 \mathrm{Mm}^{3}$ was deposited in the channels. On average, the lagoon floor deepened by about 7 $\mathrm{cm}$, while the mean depth of the channels decreased by $5 \mathrm{~cm}$.

The individual sub-basins evolved differently. In the Treporti basin (A), tidal flats and channels were almost stable ( $-1 \mathrm{~cm}$ and 0 respectively), in the Chioggia sub-basin (D), both tidal flats and channels deepened (by 4 and $5 \mathrm{~cm}$ respectively). The Malamocco (C) and Lido (B) sub-basins suffered the highest erosion of tidal flats (deepening by 10 and $9 \mathrm{~cm}$ respectively). Sub-basin C also saw the highest rate of deposition in channels $(15 \mathrm{~cm})$ followed by sub-basin $\mathrm{B}(7 \mathrm{~cm})$. In the Malamocco sub-basin (C), the high rate of deposition in channels is due to the filling-in of a large meander, which was abandoned after the dredging of the Oil Canal.

\subsubsection{Bathymetric chart comparison: 1970-2002}

The human activities that caused significant subsidence during the 1950s and 1960s were stopped in the 1970s but natural subsidence continued to influence the morphology of the lagoon. Erosion was severe in $69 \mathrm{~km}^{2}$ (17\% of the total area), concentrated particularly in the area around the Malamocco inlet (sub-basin C, $38 \mathrm{~km}^{2}$ ) and Chioggia inlet (sub-basin D, 16 $\mathrm{km}^{2}$ ). Moderate erosion affected $32 \%$ of the lagoon, especially in large areas to the north and south of the city of Venice (sub-basin B). Deposition and stability (affecting $28 \%$ and $23 \%$ of the entire lagoon respectively) prevailed in the Treporti and Lido sub-basins and were concentrated especially in the inner part of the lagoon, saltmarshes and surrounding intertidal flats (fig. 5).

The main morphological process in the 1970-2002 period was an extensive deepening, not due to subsidence, but to serious erosion. The entire area from the island of Venice to Malamocco inlet was characterised by widespread erosion of tidal flats, corresponding to $\sim 40 \mathrm{Mm}^{3}$ of sediment 
( $\sim 70 \%$ of total erosion), concentrated around the previously dredged Malamocco-Marghera ship canal. Throughout the lagoon, channels (especially the minor ones) experienced deposition involving movement of $\sim 20 \mathrm{Mm}^{3}$ of sediments from adjacent eroded tidal flats, which produced a simplification of the lagoon's morphological structure. The seaward inlets showed an erosional tendency at Malamocco and Chioggia and deposition at Lido. The process of saltmarsh erosion, significant during the $1927-1970$ period, continued in the following 30 years with a loss of $\sim 7$ $\mathrm{km}^{2}\left(\sim 9 \mathrm{Mm}^{3}\right)$, which was partially compensated by the construction of $\sim 4 \mathrm{~km}^{2}$ of artificial saltmarshes $\left(\sim 3 \mathrm{Mm}^{3}\right)$. As in the 1927-1970 period, the sheltered areas on the landward side of the lagoon were the most stable and were characterised by deposition.

Subaqueous areas deepened by an average of $\sim 19 \mathrm{~cm}$ in the lagoon as a whole, with significant differences between sub-basins. Sub-basin A was almost stable, whereas B, C and D saw average depth differences of $-9 \mathrm{~cm},-40 \mathrm{~cm}$ and $-13 \mathrm{~cm}$ respectively. Almost $15 \mathrm{~km}^{2}$ of channels accumulated sediments, and became $\sim 90 \mathrm{~cm}$ shallower than previously on average, while $8 \mathrm{~km}^{2}$ of tidal flats were dredged. Channels were characterised by both deposition and erosion, resulting in an average deposition of $\sim 40 \mathrm{~cm}$ of sediments.

\subsubsection{Continuity of erosion/deposition processes during the period 1927-2002}

The changes of sediment volume described above were combined to calculate the average rates of deposition and erosion and evaluate the continuity of deposition and erosion processes through the two examined periods (Fig. 5).

The 75-year area-weighted mean erosion rate for the entire Lagoon was $0.35 \mathrm{~cm} \mathrm{y}^{-1}$, while that of the Malamocco-Marghera sub-basin was twice as high $\left(\sim 0.7 \mathrm{~cm} \mathrm{y}^{-1}\right)$.

Comparison of the two difference maps reveal approximately $90 \mathrm{~km}^{2}$ of the LV characterized by continuous erosion $\left(\sim 1.5 \mathrm{~cm} \mathrm{y}^{-1}\right)$ throughout the 75 -year period, and $135 \mathrm{~km}^{2}$ of permanently stable or depositional areas. In contrast, $180 \mathrm{~km}^{2}$ of the LV saw a change in tendency in the second period, either towards instability (becoming erosional) or stability (becoming 
depositional). Thus, almost one-half of the lagoon experienced continuously high erosion, with a

severe increase in the final thirty-two years.

More than $35 \mathrm{~km}^{2}$ of tidal flats situated around previously dredged channels in the Malamocco and Chioggia sub-basins changed from stable or depositional conditions $\left(0-1 \mathrm{~cm} \mathrm{y}^{-1}\right)$ to severe erosion $\left(3.4 \mathrm{~cm} \mathrm{y}^{-1}\right)$, with a total deepening of $\sim 50 \mathrm{~cm}$. In contrast, nearly $30 \mathrm{~km}^{2}$ of channels characterised by severe erosion or dredging during the 1927-1970 period showed strong deposition in the following 32 years, with erosion rates changing from $-3.5 \mathrm{~cm} \mathrm{y}^{-1}$ to $+3 \mathrm{~cm} \mathrm{y}^{-1}$.

The acceleration of erosion in the central part of the lagoon is a well-known fact, although there is debate as to the causes. The already-mentioned hypothesis of Defina et al. (2007) regarding the natural deepening of lagoons with long wind fetch when lacking new sedimentary inputs could be the principal cause, but it does not explain the acceleration. A concomitant factor is suggested by Sfriso et al. (2005), who stressed the extraordinary and progressive increase in sediment suspension and removal from the tidal flats of the LV since the early 1990s due to the intensive fishing involving mechanical dredging for Manila clams.

Continuous re-suspension and alteration of the physical properties of the bottom sediment could be responsible for erosive processes causing loss of fine material from the tidal flats. These processes have markedly accelerated the deepening. The reduction of the macroalgal beds - both before and after the start of clam fishing by means of disruptive techniques - has also significantly contributed to the increase in sediment re-suspension and redistribution, favouring a loss of material and homogenisation of the grain-size and density of the surface sediment (Sfriso et al., 2005).

\subsection{Sedimentary budgets and the mass balance of the lagoon}

Studies of the evolution of recent sediment deposits in the LV are fragmented and provide information which is not readily comparable. In some cases, the erosion/sedimentation data are ambiguous since they do not make a distinction between the current status of the phenomenon and/or its evolution over the past few decades (Degetto and Cantaluppi, 2004). In addition, 
several sources of uncertainty occur when attempting to calculate a sediment budget on decadal

time scales using different methods, concerning of different temporal scales and accuracies. MAV-CVN (1996) reported an average sediment loss of about $1 \times 10^{6} \mathrm{~m}^{3}$ year ${ }^{-1}$, by analysing variations in lagoonal sediments over the previous 20 years, excluding eustatism and subsidence. Pillon et al. (2003) compared bathymetric maps from 1930, 1970 and 1990, and showed a similar average yearly sediment loss $\left(\sim 1 \times 10^{6} \mathrm{~m}^{3} \mathrm{y}^{-1}\right)$. Sarretta (2007) calculated a net removal of sediments of $0.9 \pm 0.1 \times 10^{6} \mathrm{~m}^{3} \mathrm{y}^{-1}$ between 1970 and 2000, and Molinaroli et al. (2009) have recently made a detailed comparison of 1970 and 2000 bathymetric charts, together with a comparison of sediment grain sizes, showing marked changes in both morphology and sedimentation.

\subsubsection{Volumetric differences through bathymetric comparison}

Using the maps in Fig. 3 a detailed calculation of the sediment budget was made for the two periods 1927-1970 and 1970-2002. The digitized bathymetric data were used to directly calculate the sediment volume changes between the surveys in each of the subareas. Table 3 shows all relevant data for calculating the sediment budget of the LV in the two studied periods, and Fig. 6 shows the eroded and deposited material, together with an estimate of the sediment disposed either outside the lagoon or lost through the three inlets.

\section{Insert Figure 6}

\section{Insert Table 3}

In the first period (1927-1970), dredging extracted an estimated $60 \mathrm{Mm}^{3}$ of material, and erosion of saltmarshes and tidal flats produced an additional $34 \mathrm{Mm}^{3}(18+16)$, making a total of $94 \mathrm{Mm}^{3}$. All the dredged material was disposed of outside the lagoon, approximately $35-45 \mathrm{Mm}^{3}$ on land and the remaining 15-25 $\mathrm{Mm}^{3}$ dumped into the sea outside the lagoon. Of the eroded material, 21 $\mathrm{Mm}^{3}$ was deposited inside the lagoon, either in channels $\left(17 \mathrm{Mm}^{3}\right)$ or on saltmarshes $\left(4 \mathrm{Mm}^{3}\right)$ and the remaining $13 \mathrm{Mm}^{3}$ were lost seaward through the inlets. The total sediment removal 
from the lagoon in forty-three years was thus $73 \mathrm{Mm}^{3}\left(\sim 1.7 \mathrm{Mm}^{3} \mathrm{y}^{-1}\right)$, of which the flux to the

sea through the inlets was $13 \mathrm{Mm}^{3}$, i.e. $\sim 0.3 \mathrm{Mm}^{3} \mathrm{y}^{-1}$, almost equally distributed among the four sub-basins.

In the second period (1970-2002) dredging operations extracted an estimated $11 \mathrm{Mm}^{3}$ of material, whilst erosion of saltmarshes and tidal flats lost an additional $61 \mathrm{Mm}^{3}$, making a total of $72 \mathrm{Mm}^{3}$. Approximately $3 \mathrm{Mm}^{3}$ of the dredged material was re-used to construct artificial saltmarshes and the remainder $\left(8 \mathrm{Mm}^{3}\right)$ was disposed of (on land). Of the eroded material, 35 $\mathrm{Mm}^{3}$ was deposited either in the channels $\left(32 \mathrm{Mm}^{3}\right)$ or on the saltmarshes $\left(3 \mathrm{Mm}^{3}\right)$. The total sediment removal from the lagoon in thirty-two years was thus $34 \mathrm{Mm}^{3}\left(\sim 1 \mathrm{Mm}^{3} \mathrm{y}^{-1}\right)$, of which the flux to the sea was $26 \mathrm{Mm}^{3}$, i.e. $\sim 0.8 \mathrm{Mm}^{3} \mathrm{y}^{-1}$, two-thirds of which was from sub-basin C. In this period sub-basin A experienced a net gain in sediments, either from the small rivers or from the Treporti channel at the Lido inlet.

\subsubsection{Lagoon/sea interchanges}

Direct measurements of the total mass of sediment input and output through the inlets have a high level of uncertainty. Contrasting data has recently been published, ranging from $\sim 300 * 10^{3}$ ton $\mathrm{y}^{-1}$ (Bianchi et al., 2004) to $\sim 4-500 * 10^{3}$ ton $\mathrm{y}^{-1}$ (Defendi et al., this issue) to $\sim 600 * 10^{3}$ ton $\mathrm{y}^{-1}$ (Chiarlo and Fornasiero, 2005). Those estimates refer to the present situation.

Table 4 shows the sediment budget subdivided for the four sub-basins. As in Fig. 6, it is derived from comparison of bathymetric chart. The rate of sediment loss to the sea has been transformed from $\mathrm{m}^{3}$ to tons, assuming a uniform density of $2,650 \mathrm{kgm}^{-3}$ and $50 \%$ porosity, in order to compare it with published flux data. Data on riverine input are also listed, but only for the more recent period, since no useful data are available for the period prior to 1970 . It can be seen that not only was the average total yearly loss from the lagoon quite different during the two periods ( $\sim 400$ and $\sim 1100 * 10^{3}$ ton $\left.\mathrm{y}^{-1}\right)$, but the relative rate of loss from the four sub-basins through the inlets was also very different. The rates of loss were fairly evenly distributed across the subbasins in the period $1927-1970$ (between 30 and $150 * 10^{3}$ ton $\mathrm{y}^{-1}$ ), whereas approximately $80 \%$ 
of all losses from the LV in the period 1970-2002 $\left(\sim 1100 * 10^{3}\right.$ ton $\left.\mathrm{y}^{-1}\right)$ came from the

Malamocco sub-basin alone $\left(\sim 900 * 10^{3}\right.$ ton $\left.\mathrm{y}^{-1}\right)$, while the northern sub-basins (A and B) were almost stable. In the latter period, river input was negligible for the LV as a whole (less than 3\%) but was significant for sub-basin A, which seems to be the only one which has not lost sediment and where river input may have positively affected sedimentation. Inputs could be from the turbid plume of the Piave during flooding and through Lido inlet (see Amos et al., in press).

The historical data matches quite well the estimates of Degetto and Cantaluppi (2004), who recently used radiochemical methods based on ${ }^{210} \mathrm{~Pb}$ and ${ }^{7} \mathrm{Be}$ to obtain the mass balance of particulate material exchanged at the seaward inlets of the LV. The two radionuclides were assumed to give different temporal indications, i.e., longer for ${ }^{210} \mathrm{~Pb}$ (decades) and much shorter (one-two years) for ${ }^{7} \mathrm{Be}$. The results obtained with ${ }^{7} \mathrm{Be}$ were considered reliable enough, albeit strictly limited to the period investigated (1999-2000), and showed an average yearly imbalance (sediment loss) of $\sim 800 * 10^{3}$ ton (range 300-1300) from the lagoon as a whole. The central-south lagoon was found to be the most highly eroded $\left(\sim 1100 * 10^{3}\right.$ ton $\left.\mathrm{y}^{-1}\right)$, while an accumulation of $\sim$ $300 * 10^{3}$ ton $\mathrm{y}^{-1}$ was calculated for the northern lagoon. According to Defendi et al (in press), the situation seems to have changed, since their recent surveys suggest that most of the sediment exchange between the LV and the sea $\left(\sim 600 * 10^{3}\right.$ ton $\mathrm{y}^{-1}$ in total), is through the Lido inlet $(\sim$ $400 * 10^{3}$ ton $\mathrm{y}^{-1}$ ), leaving Malamocco and Chioggia only $10 \%$ and $25 \%$ of the total budget respectively.

\section{Insert Table 4}

4.4. Relationship between variations in sediment texture and erosion/sedimentation patterns

Recently, Molinaroli et al. (2009) made a detailed comparison of LV sediment grain-size data from 1970 and 2000. The surficial sediments of the lagoon consist predominantly of clayey silts in both datasets (mean mud content was $75 \%$ for 1970 and $68 \%$ for 2000 , dry weight) (Molinaroli et al., 2007). In both datasets the silt fraction dominates over other fractions, but with a general tendency to decrease between 1970 and 2000, with the exception of basin C. In all sub- 
basins, the earlier samples have a lower sand content than the later ones. The 1970 and 2000

samples have a similar clay content, except for sub-basins A and D, where slight differences between the two datasets are observed (Table 4). The latter authors showed that there was a clear increase in sand content from 1970 to 2000 throughout sub-basins C and D, especially towards the landward side. Very high sand content is also evident in 2000 from sub-basin B and around the city of Venice. The sediment of sub-basin A does not show any significant variation (see Fig. 8 in Molinaroli et al., 2009). The authors also presented data on surficial sediments in the form of ternary diagrams based on Flemming's sand/silt/clay ratios (2000). The location of data points within the diagram reflects specific hydrodynamic energy conditions. The sediment composition of the LV is described by a diagonal band that gradually expands towards the silt-clay axis. The textural gradient in sub-basin A shows a shift towards higher silt/clay content between 1970 and 2000, indicating a general decrease in energy in this sub-basin. In sub-basin B, most of the sediments have become richer in sand, while those of sub-basins $\mathrm{C}$ and $\mathrm{D}$ have become richer in silty sands and very silty sands (see also Fig. 7 in Molinaroli et al., 2009), indicating a general increase in tractive force.

The spatial distribution of differences in sand content (Fig. 7) shows the greatest increases around the city of Venice, especially on the southern side, between the city and the industrial area of Porto Marghera and between the city and the Lido inlet. Significant sand enrichment was also found in the southern part of the lagoon around the watershed between sub-basins C and D. The spatial distribution of differences in clay shows the greatest enrichment in the northern part of the lagoon and towards the landward side, from the airport to the industrial area (see Fig. 1). Other locations in which appreciable enrichments are found are located in the southern lagoon.

\section{Insert Table 5}

Insert Figure 7 
In order to explore the relationship between variations in sediment texture and

erosion/sedimentation patterns six representative sub-areas with different erosion/deposition characteristics were selected and the average grain-size data for each of them was calculated (Fig. 8). The average differences between three grain size intervals $(<8,8-63$, and $>63 \mu \mathrm{m})$ in 1970 and 2002 were calculated and represented by histograms (Fig. 8). The six selected areas cover more than $120 \mathrm{~km}^{2}$ and show a volume of removed sediment of $26 \mathrm{Mm}^{3}$, accounting for almost one-third of the area and the sediment budget of the LV.

\section{Insert Figure 8}

\section{Insert Table 6}

There has been deposition of fine particles in the northern sub-basins (A and B-north) where there is still some riverine input from the turbid plume of the Piave during flooding and through Lido inlet (see Amos et al., in review),_and winnowing of sand in the watershed between subbasins $\mathrm{C}$ and $\mathrm{D}$. The calculated sedimentation rates are $\sim 0.3-0.4 \mathrm{~cm} \mathrm{yr}^{-1}$. Erosion of fine-grained material occured in sub-basins B-south and $\mathrm{C}$, and erosion of sand in part of sub-basin $\mathrm{D}$, around some of the channels excavated in the 1980s in connection with the Chioggia inlet. In this case the erosion rates ranged from 0.7 to $\sim 2.5 \mathrm{~cm} \mathrm{yr}^{-1}$.

These data are in agreement with radiochronological investigations conducted in the $1980 \mathrm{~s}$ and $1990 \mathrm{~s}$, which revealed a sedimentation rate of $0.3-0.5 \mathrm{~cm} \mathrm{y}^{-1}$ in the more recent deposits (Donazzolo et al., 1982; Battiston et al., 1985, 1986). Evidence of erosion was reported in the early 1990s for the southern lagoon and more recently for the central lagoon, between the industrial area and Venice (Degetto, 1997; Degetto and Cantaluppi, 2004).

Bellucci et al (2007) studied five saltmarsh sediment cores taken from around LV and found that the inventories of excess ${ }^{210} \mathrm{~Pb}$ were slightly higher than those expected from atmospheric deposition, due to some contribution from sediment re-suspended from tidal flats or eroded from 
marsh edges. Average accumulation rates were $\sim 0.3 \mathrm{~cm} \mathrm{y}^{-1}$ (range: 0.1-0.4 $\mathrm{cm} \mathrm{y}^{-1}$ ), comparable

to the average rate of mean sea level rise during the last century in Venice.

The erosion or sedimentation rates at three stations in sub-basin B and one in $\mathrm{C}$ were studied by Sfriso et al (2005) between 1989-1999. They showed that all stations in sub-basin B were affected by sediment losses, with mean erosion rates of between 0.5 and $3.6 \mathrm{~cm} \mathrm{yr}^{-1}$, while the other, despite being in the most unstable sub-basin of all (C), showed no significant bathymetric change, due to the sea-grass growing on the bed. The authors stated that their data agreed with the previous indirect estimation of sediment loss, which was based on the number of fishing boats operating in the lagoon on an annual basis.

The deterioration of the lagoon in terms of morphological and thus ecosystem complexity is mainly due to the transgressive effects caused by human-induced subsidence, superimposed on the natural sea-level rise. It has been demonstrated that in a sediment-starved lagoon such as the Lagoon of Venice, tidal flats are characterised by instability due to the effect of wave-induced currents caused by wind acting on large-fetch basins. When morphological complexity and saltmarshes are lacking, this will ultimately lead to a smooth horizontal lagoon floor of $2.0-2.5$ m deep (Defina et al., 2007; Fagherazzi et al., 2006, 2007).

Nevertheless, it does not seem that this phenomenon can alone account for the critical erosion of the Malamocco sub-basin, where the recorded modal depth in 2002 was -1.75 m, i.e. more than one metre deeper than 75 years before.

The southern lagoon experienced the intense impact of clam fishing with illegal mechanical harvesting during the 1990s due to the introduction and spread of the exotic Manila clam. In addition, the Malamocco basin also contains legal Manila clam fishing concessions, which were granted in order to control farming and exploitation. The practice had serious consequences, due to the high number of fishing boats dredging the lagoon bed, which caused re-suspension and alteration of the physical-mechanical properties of the sediment. Thus the increased susceptibility to sediment erosion due to clam fishing/harvesting, combined with 
enhanced bottom shear stress due to more powerful wind waves in a deep lagoon basin with a large fetch, could easily explain the unexpected deepening of the southern lagoon.

Insert Fig. 9

Comparison of the area distribution of elevation categories in the four sub-basins today clearly show the striking similarities between the A, B and D sub-basins and the LV as a whole in 1927, 1970 and 2002 respectively (Fig. 10). The current state of the different sub-basins (ontogenesis) reflects the historic evolution of the lagoon as a whole (phylogenesis): thus sub-basin C possibly indicates the future trend of the entire lagoon.

While this is a relatively comprehensive study of historical physical changes, it is incomplete in that the sediment budget is still uncertain. More precise quantification of the modern lagoon sediment budget will require both a better understanding of fluvial input and extraction of dredging and a sediment transport model designed to explain historical changes in the sediment budget. The combination of cartography and modelling used in this study should be applicable to other systems where large changes in morphology have occurred on historical time scales.

\section{Conclusions}

A detailed GIS-based analysis of bathymetric surveys carried out in the Lagoon of Venice in the periods 1922-1933, 1968-1971 and 1999-2003 was used to reconstruct historical sedimentation patterns. Analysis of available data on bathymetry, morphology and grain-size reveals that largescale morphological changes have been directly and indirectly caused by human actions, including navigational improvements (docks, dredged navigation channels), urban settlement, industry (water extraction for industrial plants and subsequent subsidence, filling of wetland areas) and exploitation of natural resources (fish-farming, harvesting of clams with mechanical dredges). Lesser changes are attributable to natural erosion and sedimentation.

The main results are as follows: 
1. Saltmarsh areas decreased by more than $50 \%$, from $68 \mathrm{~km}^{2}$ in 1927 to $32 \mathrm{~km}^{2}$ in 2002 .

2. The subaqueous area is progressively deepening, with the modal depth shifting from a value of $-0.62 \mathrm{~m}$ in 1927 to $-0.87 \mathrm{~m}$ in 1970 and $-0.88 \mathrm{~m}$ in 2002 . The final change seems negligible for the lagoon as a whole but is the result of a compensation effect between the erosional southern part and the stable-depositional northern part.

3. The deepening is mostly due to the areal expansion of the deepest subtidal flats (between $-0.75 \mathrm{~m}$ and $-2.00 \mathrm{~m}$ in depth), from 88 to $206 \mathrm{~km}^{2}$ during $1927-2002$.

4. Depth increases in the 75 year-period mainly affected the Malamocco sub-basin, which increased from -0.64 to $-1.75 \mathrm{~m}$ on average, followed by Chioggia, from $-0.39 \mathrm{~m}$ to -0.88 $\mathrm{m}$, and Lido, from $-0.65 \mathrm{~m}$ to $-1.12 \mathrm{~m}$.

5. There has been a net loss of about $110 \mathrm{Mm}^{3}$ of sediment from the $\mathrm{LV}$, the majority of which $\left(73 \mathrm{Mm}^{3}\right.$, about $\left.70 \%\right)$ occurred during the first period. A significant amount was lost by direct disposal of dredged sediment outside the LV, either on land or at sea, whilst $39 \mathrm{Mm}^{3}$ was lost from the lagoon to the sea throughout the inlets, at an annual average rate of $0.5 \mathrm{Mm}^{3}$.

6. Considering only the net export of lagoon material to the sea, sedimentary budget calculations revealed an alarming acceleration of erosion, from a net sediment loss of 0.3 $\mathrm{Mm}^{3} \mathrm{y}^{-1}$ during $1927-1970$ to $0.8 \mathrm{Mm}^{3} \mathrm{y}^{-1}$ in $1970-2002$. As a consequence, the lagoon was transformed from a highly complex, well-developed microtidal lagoon during the 1930s, to a sediment-starved and subsidence-dominated lagoon in the 1970s, and then to the high energy-dominated, flatter-bottomed and more open (bay-like) environment of today, where the simplified morphology and increased depth of the lagoon bed favour water exchange with the sea, thus weakening its estuarine features.

\section{Acknowledgements}


We thank the Magistrato alle Acque di Venezia for providing data. Mr. George Metcalf revised the English text. We are grateful to Prof. Graham Evans, an anonymous reviewer and the editor Carl L. Amos for their careful review, comments and suggestions. This work was financially supported by a research contract with the former ICRAM (now ISPRA) - Italian Ministry of the Environment and by the FISR Project "Vector", Research Line 3 (responsible F.Antonioli). 


\section{References}

Albani, A.D., Serandrei Barbero, R., 2001. The distribution of surface sediments in the lagoon of Venice (Italy) in the 1980s. Atti Istituto Veneto di Scienze Lettere ed Arti 159, 363-378.

Apitz S.E., Barbanti, A., Bernstein, A.G., Bocci, M., Delaney, E., Montobbio, L., 2007. The assessment of sediment screening risk in Venice Lagoon and other coastal areas using international sediment quality guidelines. Journal of Soils and Sediments 7 (5), 326-341.

Battiston, G., Croatto, U., Degetto, S., Sbrignadello, G. and Tositti, L., 1985. Tecniche radioisotopiche nella datazione di sedimenti recenti. Inquinamento 6, 49-58.

Battiston, G., Croatto, U., Degetto, S., Sbrignadello, G. and Tositti, L., 1986. Studi sulla diffusione e distribuzione di inquinanti antropogenici mediante tecniche radioisotopiche di datazione di sedimenti recenti. Ambiente Risorse 1, 81-87.

Bellucci, L.G., Frignani, M., Cochran, J.K., Albertazzi, S., Zaggia, L., Cecconi G., Hopkins, H., 2007. ${ }^{210} \mathrm{~Pb}$ and ${ }^{137} \mathrm{Cs}$ as chronometers for salt marsh accretion in the Venice Lagoon and links to flooding frequency and climate change. Journal of Environmental Radioactivity 97, 85-102.

Bianchi, F., Ravagnan, E., Acri, F., Bernardi-Aubry, F., Boldrin, A., Camatti, E., Cassin, D., Turchetto, M., 2004. Variability and fluxes of hydrology, nutrients and particulate matter between the Venice Lagoon and the Adriatic Sea. Preliminary results (years 2001-2002). Journal of Marine Systems 51, 49-64.

Bonometto, L., 2005. Functional characteristics of salt marshes (barene) in the Venice Lagoon and environmental restoration scenarios. In: Fletcher, C.A., Spencer, T. (Eds.), Flooding and environmental challenges for Venice and its lagoon: state of knowledge. Cambridge University Press, Cambridge, UK, pp. 473-486.

Brambati, A., Carbognin, L., Quaia, T., Teatini, P., Tosi, L., 2003. The Lagoon of Venice: geological setting, evolution and land subsidence. Episodes 26, 264-268.

Bromberg Gedan, K., Silliman, B.R., Bertness, M.D., 2009. Centuries of human-driven change in salt-marsh ecosystems. Annual Review of Marine Science 1, 117-141

Carbognin, L., Teatini, P., Tosi, L., 2004. Eustacy and land subsidence in the Venice Lagoon at the beginning of the new millennium. Journal of Marine System 51, 345-353.

Cavaleri L., 1980. Sediment transport in shallow lagoons. Il Nuovo Cimento 3C (5), 527-540.

Cavazzoni, S., 1977. Variazioni batimetriche ed idrografiche nella Laguna di Venezia, intercorse tra il 1933 e il 1971. Istituto Veneto di Scienze Lettere ed Arti, Rapporti e Studi 7, 1-18. 
Cesari, P., Pellizzato, M., 1985. Insediamento nella Laguna di Venezia e distribuzione adriatica di Rapana venosa (Valenciennes) (Gastropoda, Thaididae). Lavori Società Veneta di Scienze Naturali 10, 3-16.

Chiarlo, R., Fornasiero, P., 2005. The ADCP measurements + Sediview method: a rigorous approach to estimate solid concentration and solid discharge. 4th ADCPs in Action Users Conference, April 4-6, 2005, San Diego, California (USA).

Cossu, R., De Fraja Frangipane, E., 1985. Stato delle conoscenze sull'inquinamento della laguna di Venezia. Consorzio Venezia Nuova, Servizio Informativo, Technical Report, (Vol. I-IV), 438 pp.

Day, J.W., Scarton, F., Rispondo, A., Are, D., 1998. Rapid deterioration of a salt marsh in Venice Lagoon. Journal of Coastal Research 14, 583-590.

Defendi, V., Zaggia, L., Kovačević V., (this issue) Estimating suspended sediment transport from acoustic measurements in the Venice Lagoon inlets,.

Defina, A., Carniello, A., Fagherazzi, S., D’Alpaos, L. 2007. Self-organization of shallow basins in tidal flats and salt marshes. Journal of Geophysical Research 112, F03001, doi:10.1029/2006JF000550.

Degetto, S., 1997. Passato e presente dell'inquinamento lagunare attraverso l'analisi di carote sedimentarie radiodatate. Proceedings of the Conference "Salvaguardia Ambientale e Sviluppo Sostenibile", Universita Cà Foscari, Venice, Italy, pp. 36-57.

Degetto, S., Cantaluppi, C., 2004. Radiochemical methodology for the determination of the mass balance of suspended particulate materials exchanged at the inlets of the Venice Lagoon. Journal of Marine System 51, 77-94

Donazzolo, R., Orio, A, Pavoni, B., 1982. Radiometric dating and pollutants profiles in a sediment core from the Lagoon of Venice. Oceanologica Acta 4 Suppl., 101-106.

Dorigo L., 1961. Le osservazioni mareografiche in Laguna di Venezia. Istituto Veneto di Scienze Lettere ed Arti. Commissione di Studio dei Provvedimenti per la Conservazione e Difesa della Laguna e della Città di Venezia, Rapporti Preliminari I, Stamperia di Venezia, 11-38.

Fagherazzi, S., Carniello, L., D’Alpaos, L., Defina, A., 2006. Critical bifurcation of shallow microtidal landforms in tidal flats and salt marshes. Proceedings of the National Academy of Sciences of the United States of America, PNAS 103, 8337-8341.

Fagherazzi, S., Palermo, C., Rulli, M.C., Carniello, L., Defina, A., 2007, Wind waves in shallow microtidal basins and the dynamic equilibrium of tidal flats. Journal of Geophysical Research 112, F02024, doi:10.1029/2006JF000572.

Favero, V., 1992. Evoluzione morfologica e trasformazioni ambientali dalla conterminazione lagunare al nostro secolo. In: Conterminazione lagunare: storia, ingegneria, politica e 
diritto nella Laguna di Venezia. Proceeding of the Conference "Convegno di studio nel bicentenario della conterminazione lagunare”, Venice, Italy, 14-16 March 1991, Istituto Veneto di Scienze Lettere ed Arti, Tipografia La Garangola, Padova, pp. 165-184.

Ferla, M., Cordella, M., Michielli, L., 2006. Aggiornamenti sulle osservazioni dei livelli di marea a Venezia. Agenzia per la Protezione dell'Ambiente e per i Servizi Tecnici, APAT, Rapporti 69, Technical Report.

Flemming, B.W., 2000. A revised textural classification of gravel-free muddy sediments on the basis of ternary diagrams. Continental Shelf Research 20, 1125-1137.

Fontana, A., Mozzi, P., Bondesan, A., 2004, L'evoluzione geomorfologica della pianura veneto-friulana. In: Bondesan, A., Meneghel, M., (Eds.), Geomorfologia della Provincia di Venezia. Esedra Editrice, Padova, Italy, pp. 113-138.

Gatto, P., Carbognin, L., 1981. The lagoon of Venice: natural environmental trend and maninduced modification. Hydrological Sciences Bulletin 26 (4), 379-391.

Guerzoni, S., Tagliapietra, D., 2006. Atlante della Laguna. Venezia tra terra e mare (Atlas of the Lagoon: Venice between land and sea). Marsilio, Venice, $242 \mathrm{pp}$.

Higgins, S.A., Jaffe, B., Fuller, C.C., 2007. Reconstructing sediment age profiles from historical bathymetry changes in San Pablo Bay, California. Estuarine Coastal and Shelf Sciences 73, 165-174.

Jaffe, B.E., Smith, R.E., Foxgrover, A.C., 2007. Anthropogenic influence on sedimentation and intertidal mudflat change in San Pablo Bay, California: 1856-1983. Estuarine, Coastal and Shelf Sciences 73, 175-187.

Longley, P.A., Goodchild, M., Maguire, D.J., Rhind, D.W., Lobley, J., 2001. Geographic information systems and science. John Wiley \& Sons, Chichester, UK. 454 pp.

Marani, M., D’Alpaos, A., Lanzoni, S., Carniello, L., Rinaldo, A., 2007. Biologicallycontrolled multiple equilibria of tidal landforms and the fate of the Venice lagoon. Geophysical Research Letters 34, L11402, doi:10.1029/2007GL030178.

Ministero Ambiente, 1993. Protocollo recante criteri di sicurezza ambientale per gli interventi di escavazione, trasporto e reimpiego dei fanghi estratti dai canali di Venezia -8 Aprile 1993, Venice, Italy, Technical Report.

MAV-CVN, 1996. Studio C.4.5/1. Monitoraggio dello sviluppo di velme e barene. Studio per la formulazione di indirizzi e criteri esecutivi generali. Dati sui sedimenti lagunari. Magistrato alle Acque di Venezia, Consorzio Venezia Nuova, Venice, Italy, Technical Report. 
MAV-CVN, 1999. Mappatura dell'inquinamento dei fondali lagunari. Studi ed indagini, relazione finale luglio 1999. Magistrato alle Acque di Venezia, Consorzio Venezia Nuova, Venice, Italy, Technical Report.

MAV-CVN, 2004. Attività di aggiornamento del piano degli interventi per il recupero morfologico in applicazione della delibera del Consiglio dei Ministri del 15 Marzo 2001. Studi di base, linee guida e proposte di intervento del piano morfologico. Magistrato alle Acque di Venezia, Consorzio Venezia Nuova, Venice, Italy, Technical Report.

Molinaroli, E., Guerzoni, S., Sarretta, A., Masiol, M., Pistolato, M., 2009. Thirty-year changes (1970 to 2000) in bathymetry and sediment texture recorded in the Lagoon of Venice sub-basins, Italy. Marine Geology 258, 115-125.

Molinaroli, E., Guerzoni, S., Sarretta, A., Cucco, A., Umgiesser, G., 2007. Link between hydrology and sedimentology in the Lagoon of Venice, Italy. Journal of Marine System 68, 303-317.

Pinder, D.A,,Witherick, M.E., 1990. Port industrialization, urbanization and wetland loss. In: Williams, M., (Ed.), Wetlands: A Threatened Landscape, Blackwell, Oxford, UK, pp. 235266.

Pranovi, F., Da Ponte, F., Raicevich, S., Giovanardi, O., 2004. A multidisciplinary study of the immediate effects of mechanical clam harvesting in the Venice Lagoon. ICES Journal of Marine Science 61 (1), 43-52.

Pranovi, F., Franceschini, G., Casale, M., Zucchetta, M., Torricelli, P., Giovanardi, O., 2006. An ecological imbalance induced by a non-native species: the Manila clam in the Venice Lagoon. Biological Invasions 8 (4), 595-609.

Provincia di Venezia, 2000. Piano per la gestione delle risorse alieutiche delle lagune della provincia di Venezia. Provincia di Venezia, Venice.

Pillon, S., Fontolan, G., Bezzi, A., Burla, I., Tessari, U., Simeoni, U., Zamariolo, A., Tromellini, E., Gabellini, M., 2003. A GIS-based morphological evolution of the Venice Lagoon. In: Proc. VI Int. Conf. on Med. Coast. Env. MEDCOAST03, 2, 1269-1280.

Ravera, O., 2000. The Lagoon of Venice: the result of both natural factors and human influence. Journal of Limnology 59 (1), 9-30.

Rusconi, A., 1987. Variazioni delle superfici componenti il bacino lagunare. Ufficio Idrografico del Magistrato alle Acque, Pubblicazione n. 160, Tipoffset Gasparoni, Venezia.

Sarretta, A., 2007. Integrazione di dati granulometrici e informazioni ambientali nella laguna di Venezia per lo studio degli habitat di fondo. Ph.D thesis, Università Ca' Foscari Venezia Italy, unpublished. 
Scarton, F., Day, J.W., Rismondo, A., Lecconi, G., Are, D., 2000. Effects of an intertidal

sediment fence on sediment elevation and vegetation distribution in a Venice (Italy) lagoon salt marsh. Ecological Engineering 16, 223-233.

Sfriso, A., Facca, C., Marcomini, A., 2005. Sedimentation rates and erosion processes in the lagoon of Venice. Environment International, Special Issue 31, 983-992.

Silliman, B.R., Grosholz, E., Bertness, M.D., in press. A synthesis of anthropogenic impacts on North American salt marshes. In: Silliman, B.R., Bertness, M.D., Strong, D., (Eds.), Anthropogenic Modification of North American Salt Marshes, University of California Press, Berkeley, CA.

Silvestri, S., Defina, A., Marani, M., 2005. Tidal regime, salinity and salt marsh plant zonation. Estuarine Coastal and Shelf Science 62, 119-130.

Vatova, A., 1940. Le zoocenosi della laguna veneta. Thalassia 3 (10), 1-28.

Vatova, A., 1949. Caratteri di alcune facies bentoniche della laguna veneta. Nova Thalassia 1 (4), 1-15.

Zonta, R., Bettiol, C., Collarini, F., Fagarazzi, O.E., Zaggia, L., Zuliani, A., 2001. DRAIN Project - Fresh water and pollutant transfer from the drainage basin to the Venice Lagoon. Project Report N. 15B, Venice Italy, pp. 1-61. 


\section{FIGURE CAPTIONS}

Figure 1 - The Lagoon of Venice and four sub-basins (A to D), separated by broken lines.

Figure 2 - (a) Mean sea level for Venice and Trieste compared to reference datums. Moving averages (11 years) are in bold. (b) Absolute difference in mean sea level between Venice and Trieste. Sea level data conventionally refer to a plane located $150 \mathrm{~cm}$ below the National Altimetric Network Zero (NANZ).

Figure 3 - Colour-shaded bathymetric maps of Lagoon of Venice (from left to right: 1927, 1970; 2002). Dotted red line indicates migration of $-1.2 \mathrm{~m}$ contour line, showing an overall increase in depth (progressively darker blue colour). Emergent areas are indicated in green.

Figure 4 - The Distribution of surface areas of specific elevation categories in 1927 ( dotted line), 1970 (dashed line) and 2002 (solid line) in whole Lagoon of Venice (central plot) and sub-basins A to D.

Figure 5 - Colour shaded sedimentation maps for 1927-1970 (left) and 1970-2002 (centre), and map of continuity/change in sedimentary regime from first to second period (right). Severe erosion means altimetric differences of $<-0.5 \mathrm{~m}$, moderate erosion means differences of between -0.5 and $-0.1 \mathrm{~m}$, stability means differences within \pm $0.1 \mathrm{~m}$, deposition means differences of $>0.1 \mathrm{~m}$. Histograms show regimes of the four sub-basins in the two periods. Continuous erosion was seen mainly in the subtidal flats. Continuously stable and depositional areas are mainly saltmarshes; changes towards erosion (instability) result from enlargement of permanent erosion areas; changes towards deposition result mostly from channel infilling.

Figure 6 - The sediment budget for whole lagoon (left:1927-70; right: 1970-2002). Riverine input was considered negligible. An unknown portion of dredged material was probably handled more than once. Dashed arrows refer to a negative budget (erosion or dredging), solid arrows indicate a positive budget (sedimentation). Numbers inside circles are the sum of dredged (grey) and eroded (black) material from tidal flats and saltmarshes. Net loss is the result of a balance between eroded and re-sedimented material. $20 \mathrm{Mm}^{3}$ of dredged sediment were dumped offshore 
during 1930-1970, whereas during 1970-2002, dredged material was partially reused for morphological reconstruction (artificial marshes).

Figure 7 - Differences between 2000 and 1970 in distribution of sand ( $>63 \mu \mathrm{m}$, left) and clay $(<2 \mu \mathrm{m}$, right).

Figure 8 - Grain-size variations from 1970 to 2000 in six sub-areas (areas I, II, V = deposition; II, IV, VI = erosion; see Fig. 5 for colour code). Histograms show combined grain size intervals $(<8,8-63$, and $>63 \mu \mathrm{m})$

Figure 9 - Comparison of area distribution of elevation categories. Above: sub-basins A, B, C and D in 2002; below: whole Lagoon of Venice in 1927, 1970 and 2002 . Note similarities between A, B and D and three historic periods. Evolution of different sub-basins (ontogenesis) reflects the historic evolution of whole lagoon (phylogenesis). Sub-basin C may indicate future trend of entire lagoon. 


\section{TABLE CAPTIONS}

Table 1- Chronology of events recognized as strong factors able to affect structures and processes in the morpho-bathymetry of LV between 1927 and 2002.

Table $2 \mathrm{a}$ - Area and areal changes of depth range for 1927, 1970 and 2002; the entire lagoon.

Table $2 b$ - Area by depth range for 1927, 1970 and 2002 for each sub-basin

Table $2 \mathrm{c}$ - Areal changes of depth range for 1927, 1970 and 2002 for each sub-basin

Table 3 - Relevant data for the entire lagoonal sediment budget calculation in the two studied periods. The budgets derive from bathymetric chart comparison. The data on dredged material disposed of on land was supplied by MAV; the difference indicated was lost though inlets.

Table 4 - The relevant data for calculating sediment budget of each sub-basin during the two studied periods. Rates of sediment loss to sea were averaged for 43 years and 32 years respectively and compared with riverine input. The riverine data for period 1970-2002 are from Collavini et al.(2005) and refer to years 1999-2000.

Table 5 - Mean values and ranges (in brackets) of surficial sediment grain-size of tidal flats inside each lagoonal sub-basin; (after Molinaroli et al., 2009, modified)

Table 6- Relevant data for six zones shown in figure 9 
Fig. 1

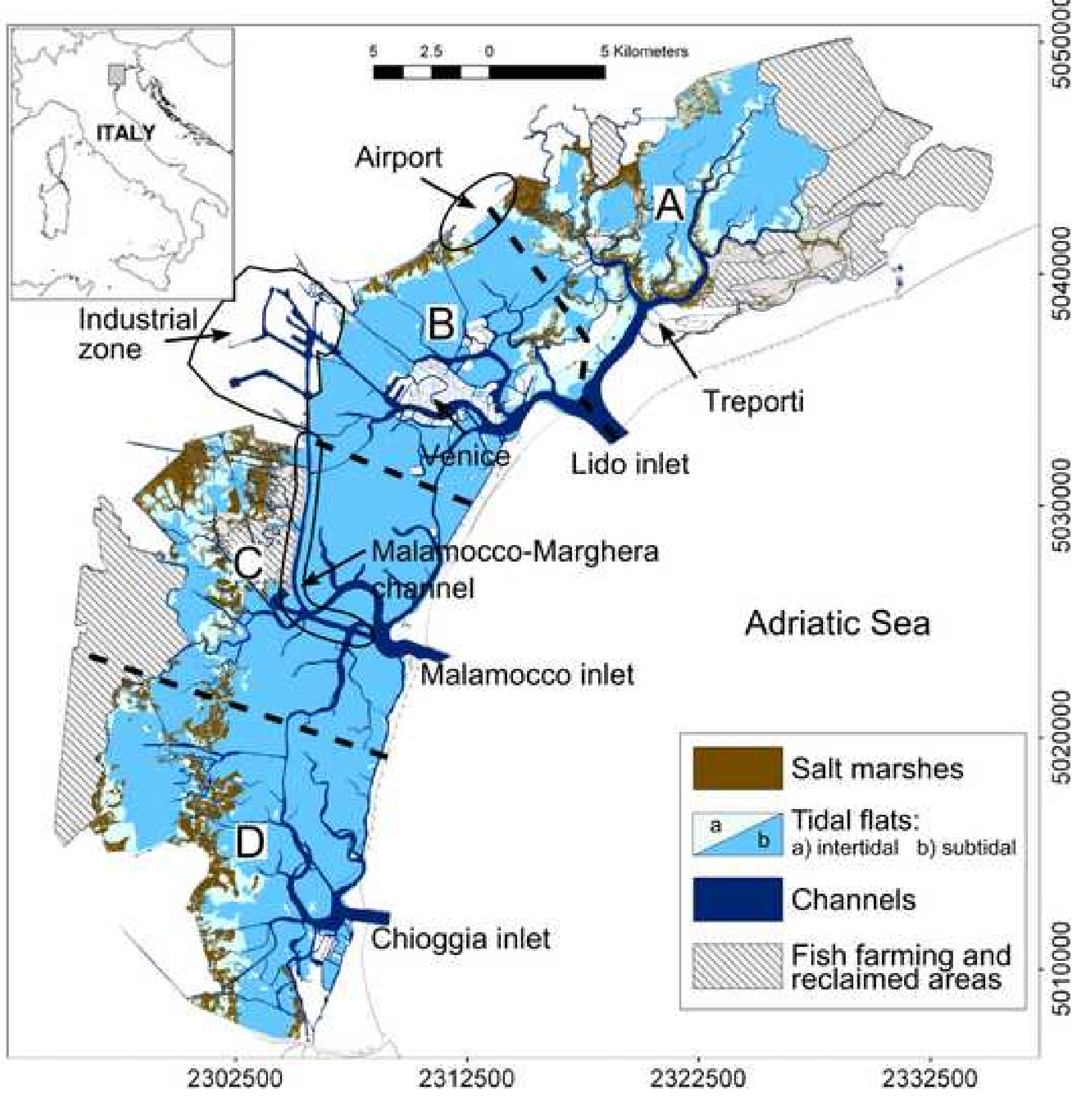



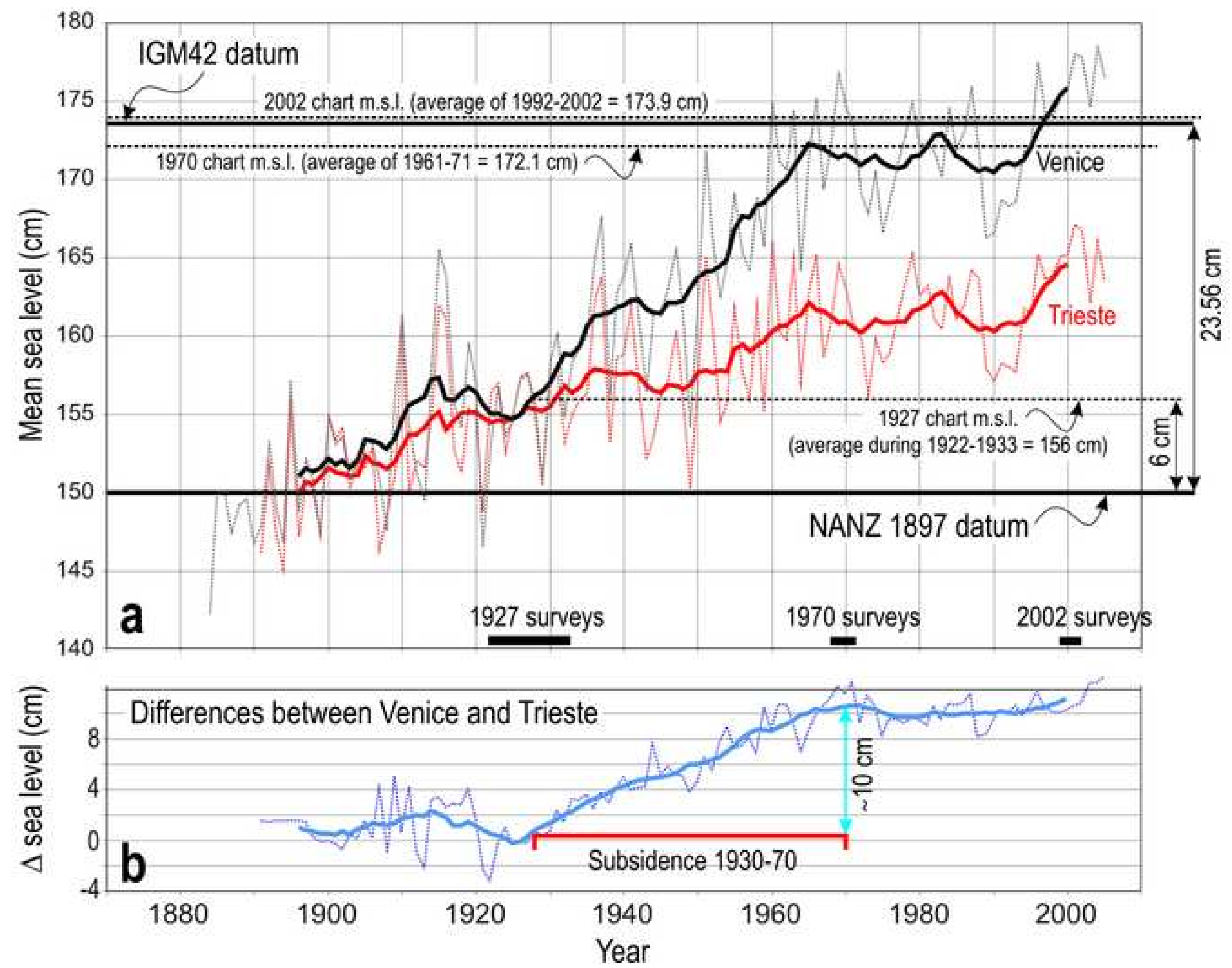

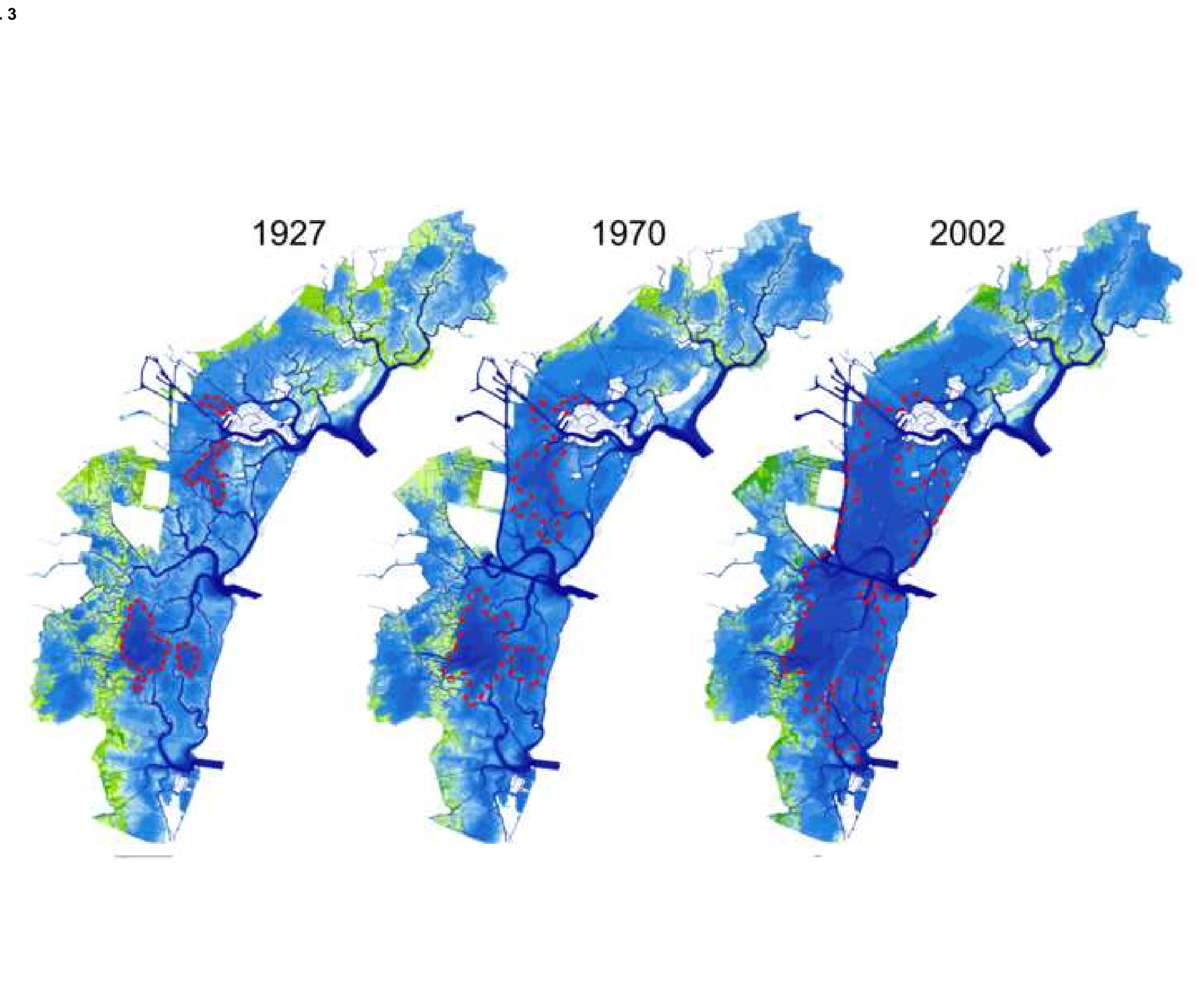
Fig. 4
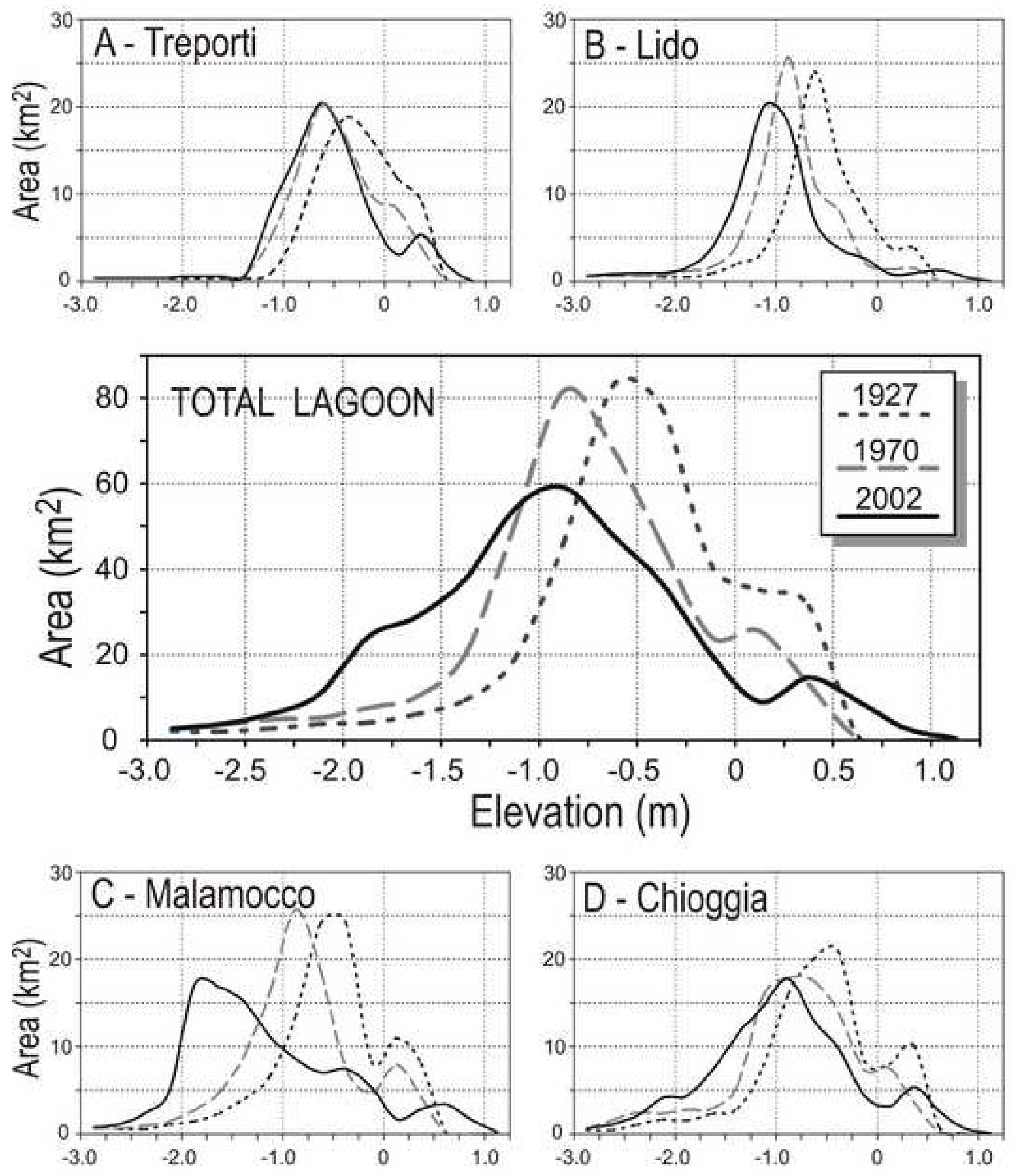

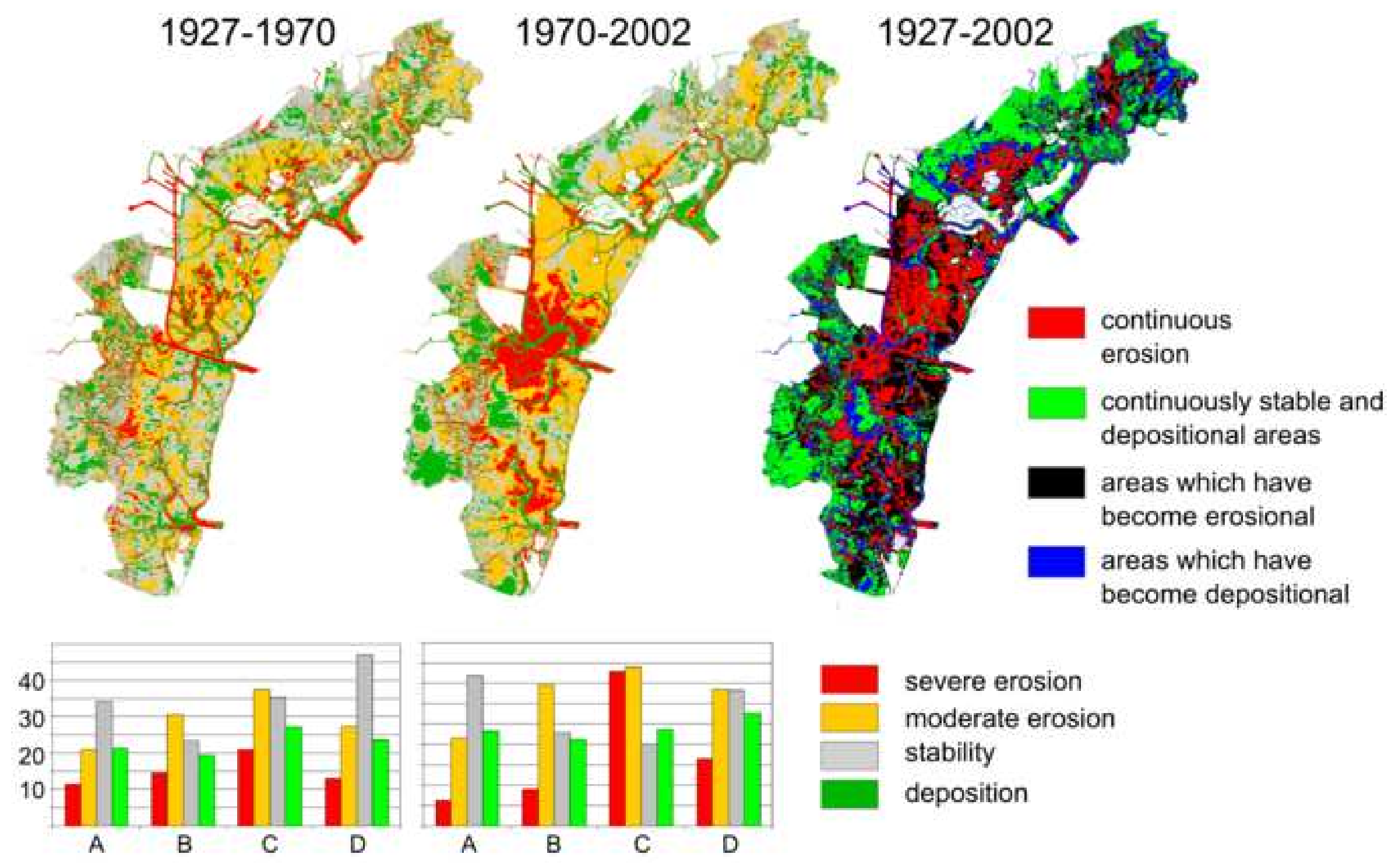

severe erosion moderate erosion stability

deposition
(n) 

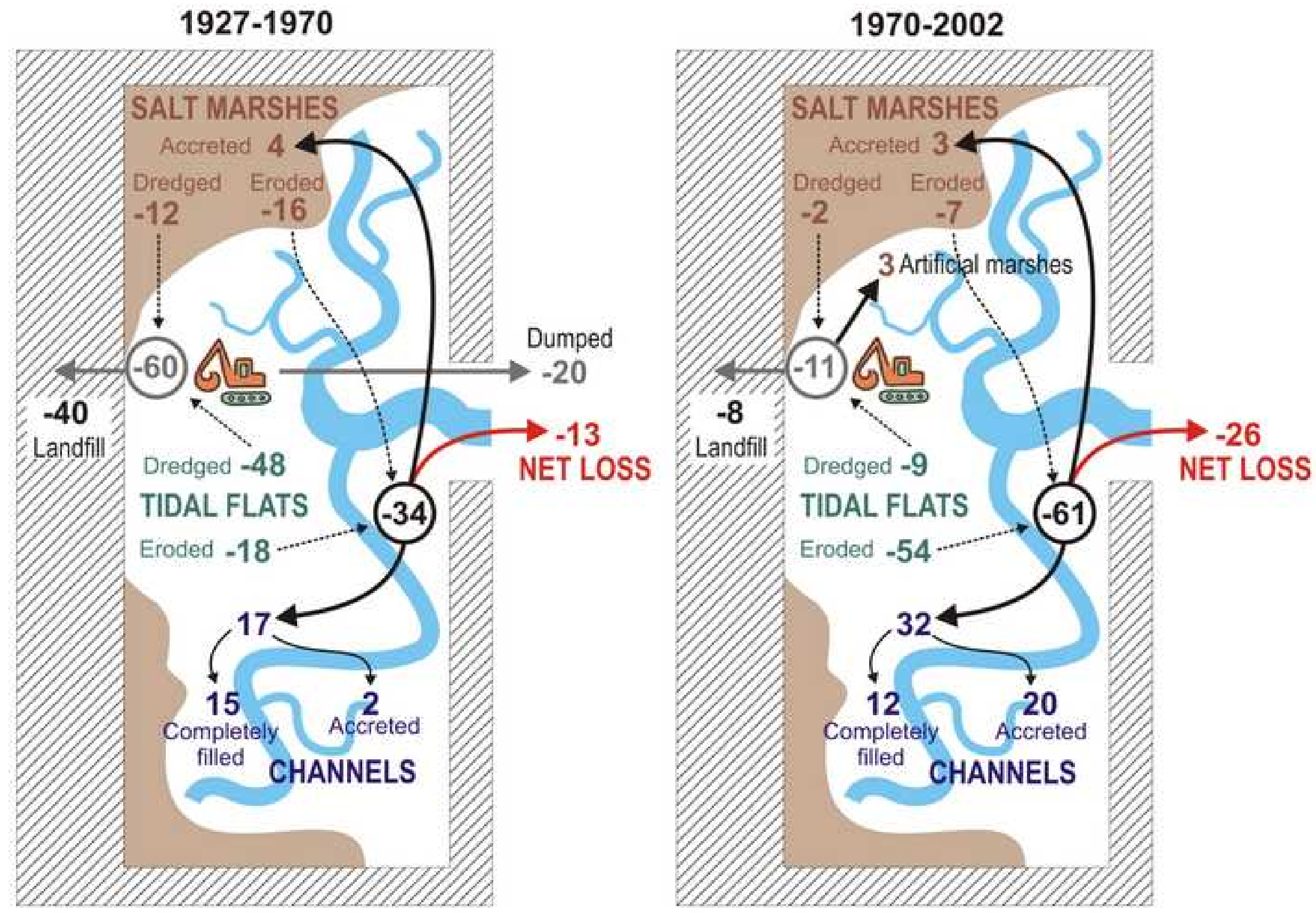


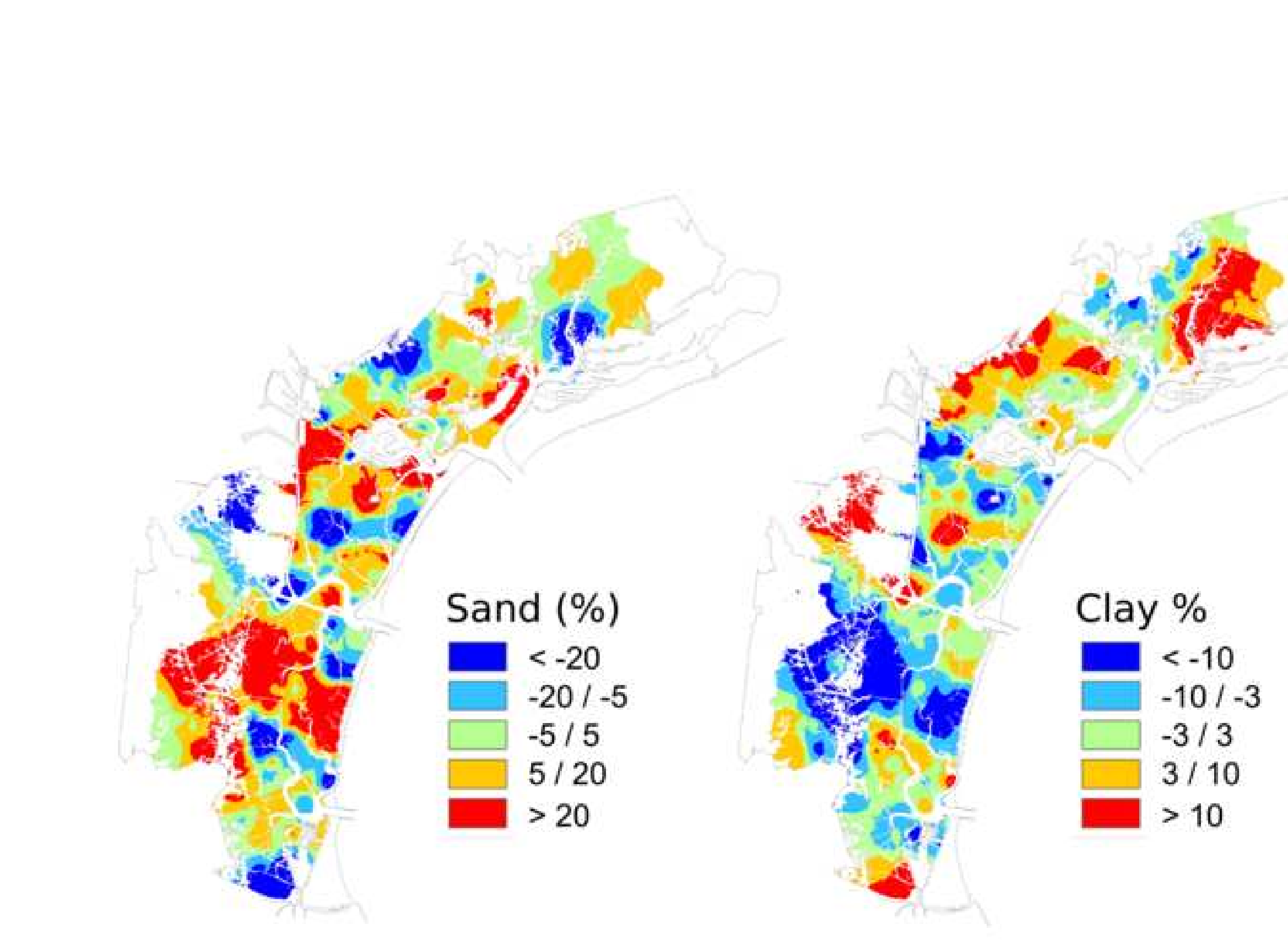

- $<-20$

$5 / 20$

$>20$

$-20 /-5$

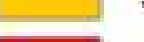

$-10$

$-3 / 3$

$\square / 10$
$\square$

$3 / 10$
$>$

Sand (\%)
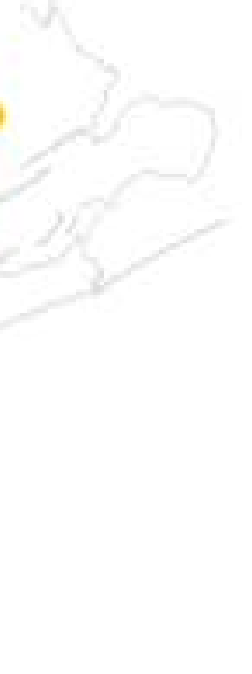$$
-10<-10
$$

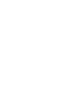



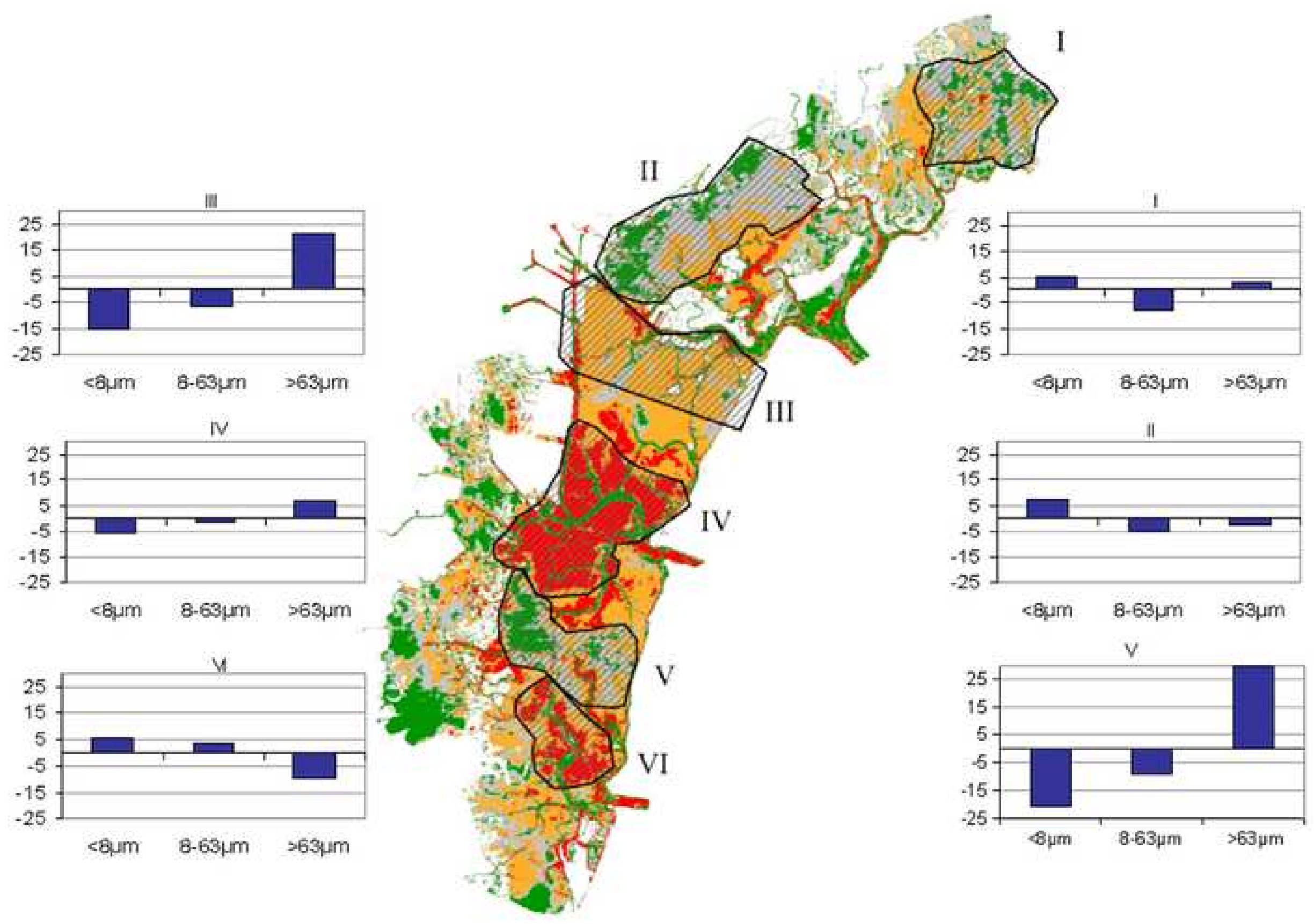


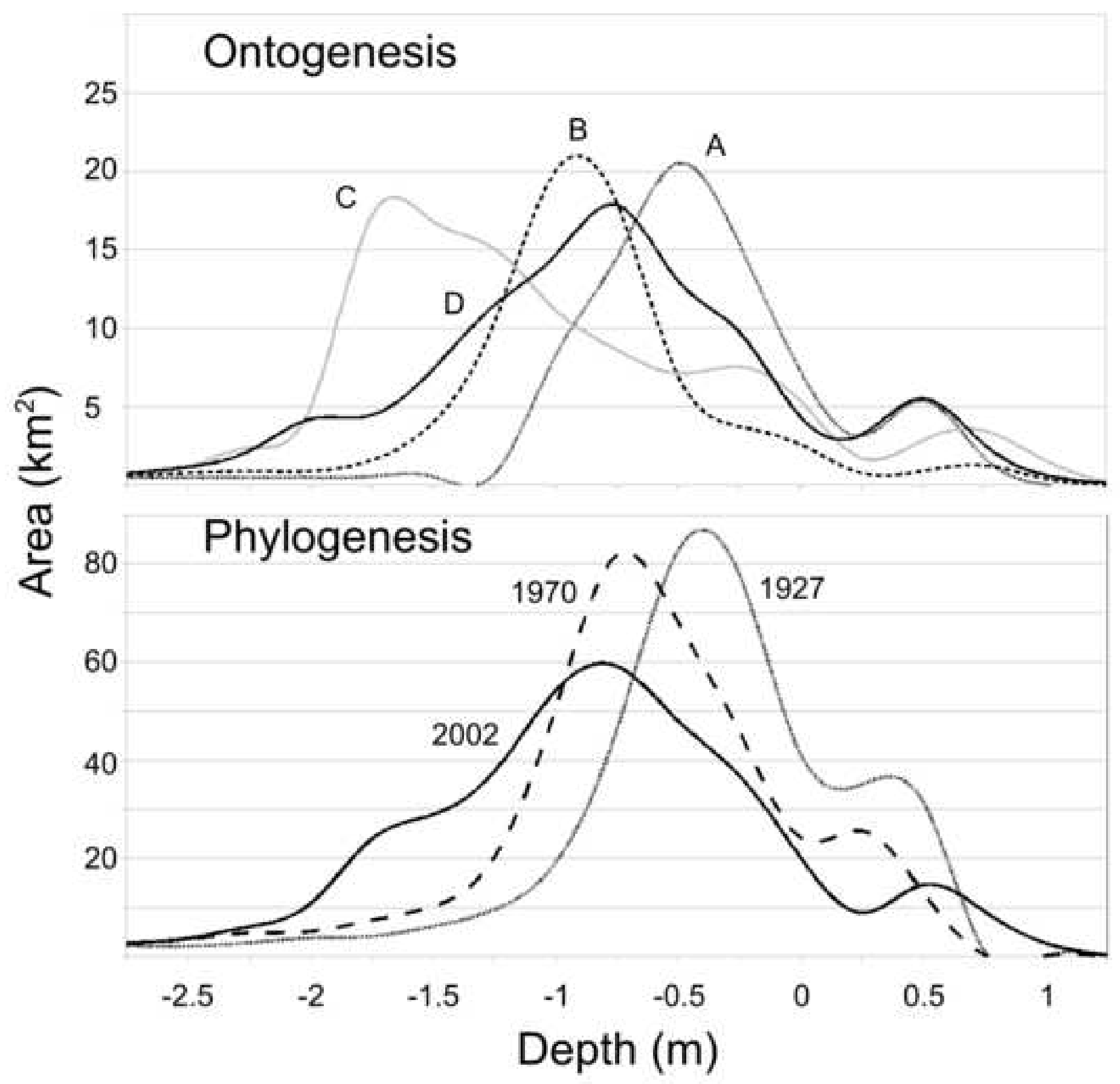

Fig. 9 


\begin{tabular}{|c|c|c|}
\hline $\begin{array}{l}\text { FIRST } \\
\text { PERIOD }\end{array}$ & EVENT & NOTES \\
\hline $1910-1934$ & new harbour walls at Chioggia inlet & modification of lagoon-sea exchanges \\
\hline 1928 & fish farming areas separated from rest of LV & $\begin{array}{l}\text { reduction of lagoon surface area }\left(85 \mathrm{~km}^{2}\right) / \\
\text { reduction of water residence time }\end{array}$ \\
\hline $1917-1935$ & Iand reclamation for $1^{\text {st }}$ Industrial Zone (IZ) & $\begin{array}{l}\text { saltmarsh destruction, }\left(5 \mathrm{~km}^{2} \text {, West of City of }\right. \\
\text { Venice })\end{array}$ \\
\hline 1931-34 & $\begin{array}{l}\text { construction of trans-lagoon bridge (Ponte della } \\
\text { Libertà) }\end{array}$ & modification of tidal current pattern \\
\hline $1950-53$ & land reclamation for $2^{\text {nd }}$ Industrial Zone & saltmarsh destruction $\left(5 \mathrm{~km}^{2}\right.$, South of $\left.1^{\text {st }} \mathrm{IZ}\right)$ \\
\hline 1957 & $\begin{array}{l}\text { land reclamation for housing (S. Giuliano, east of } \\
\text { Mestre) }\end{array}$ & $\begin{array}{l}\text { saltmarsh destruction }\left(2 \mathrm{~km}^{2} \text {, North of trans-lagoon }\right. \\
\text { bridge })\end{array}$ \\
\hline $1958-1962$ & airport construction & $\begin{array}{l}\text { saltmarsh destruction }\left(\sim 3 \mathrm{~km}^{2)} \text {, excavation of new }\right. \\
\text { artificial canal from airport to Venice city }\end{array}$ \\
\hline 1962 & $\begin{array}{l}\text { land reclamation for } 3^{\text {rd }} \text { Industrial Zone (never } \\
\text { completed), now called "Casse di Colmata", i.e. } \\
\text { unfinished reclamation islands }\end{array}$ & saltmarsh destruction $\left(12 \mathrm{~km}^{2}\right.$, South of $\left.2^{\text {nd }} \mathrm{IZ}\right)$ \\
\hline $1966-1969$ & $\begin{array}{l}\text { excavation of Malamocco-Marghera navigation } \\
\text { channel (“Oil Canal”) }\end{array}$ & $\begin{array}{l}30-50 \mathrm{Mm}^{3} \text { of sediments disposed of in landfill } \\
\text { areas outside the lagoon / modification of } \\
\text { hydrodynamic conditions }\end{array}$ \\
\hline $1930-1970$ & major development of Industrial activities & $\begin{array}{l}\text { from } 1932 \text { to } 1972, \sim 12 \mathrm{~cm} \text { of subsidence were due } \\
\text { to water extraction for industrial use }\end{array}$ \\
\hline \multicolumn{3}{|l|}{$\begin{array}{l}\text { SECOND } \\
\text { PERIOD }\end{array}$} \\
\hline from '70s on & dredging of Porto Marghera channels & $\begin{array}{l}\text { disposal of } 5-15 \mathrm{Mm}^{3} \text { of polluted sediments, in part } \\
\text { outside lagoon }\end{array}$ \\
\hline $1970-1980$ & $\begin{array}{l}\text { increased discharges from Industrial area } \\
\text { (nutrients, metals, POPs) }\end{array}$ & $\begin{array}{l}\text { part of sediments becoming more and more } \\
\text { polluted, and thus not suitable for re-use inside } \\
\text { lagoon }\end{array}$ \\
\hline $80 s$ & $\begin{array}{l}\text { eutrophication and subsequent macro algae } \\
\text { blooms and anoxia }\end{array}$ & $\begin{array}{l}\text { Lagoon bed covered by high quantity of biomass } \\
\text { (up to } 10-25 \mathrm{~kg} \mathrm{~m}^{-2} \text { ) }\end{array}$ \\
\hline middle '80s & $\begin{array}{l}\text { introduction of Manila clam for aquaculture } \\
\text { purposes }\end{array}$ & $\begin{array}{l}\text { concession of lagoon areas }\left(\sim 14 \mathrm{~km}^{2}\right) \text { for clam } \\
\text { cultivation and harvesting (seagrass loss, sediment } \\
\text { re-suspension and alteration of physical properties) }\end{array}$ \\
\hline from 1990 & dredging for renovation of Port area & $\begin{array}{l}3-5 \mathrm{Mm}^{3} \text { of sediments, partly disposed of outside } \\
\text { lagoon }\end{array}$ \\
\hline 1992 & $\begin{array}{l}\text { construction of artificial "Tresse" island to dispose } \\
\text { of polluted industrial waste }\end{array}$ & saltmarsh destruction $\left(\sim 2 \mathrm{~km}^{2}\right)$ \\
\hline $90 \mathrm{~s}$ & "invasion" of LV by Manila clam & $\begin{array}{l}\text { disturbance of sediments through mechanical clam } \\
\text { harvesting }\end{array}$ \\
\hline $1990-2000$ & construction of artificial saltmarshes $\left(\sim 4 \mathrm{~km}^{2}\right)$ & $\begin{array}{l}\text { Re-use of non polluted sediments dredged from } \\
\text { channels }\left(3-4 \mathrm{Mm}^{3}\right)\end{array}$ \\
\hline
\end{tabular}


Tab. $2 \mathrm{a}-$

\begin{tabular}{c|c|c|c|c|c|c}
\hline & \multicolumn{3}{|c|}{ Area $\left(\mathrm{km}^{2}\right)$} & \multicolumn{3}{c}{ Area changes $\left(\mathrm{km}^{2}\right)$} \\
\hline $\begin{array}{c}\text { Depth } \\
\text { interval } \\
(\mathbf{m})\end{array}$ & $\mathbf{1 9 2 7}$ & $\mathbf{1 9 7 0}$ & $\mathbf{2 0 0 2}$ & $\begin{array}{c}\mathbf{1 9 7 0 -} \\
\mathbf{1 9 2 7}\end{array}$ & $\begin{array}{c}\mathbf{2 0 0 2 -} \\
\mathbf{1 9 7 0}\end{array}$ & $\begin{array}{c}\mathbf{2 0 0 2 -} \\
\mathbf{1 9 2 7}\end{array}$ \\
\hline$<\mathbf{2 5}$ & 0 & 0 & 0 & 0.0 & 0.0 & 0.0 \\
$\mathbf{- 2 5 / - 2 0}$ & 0 & 0 & 0 & 0.0 & 0.1 & 0.1 \\
$\mathbf{- 2 0 / - 1 5}$ & 1 & 2 & 2 & 1.1 & 0.0 & 1.0 \\
$\mathbf{- 1 5 / - 1 0}$ & 5 & 7 & 6 & 2.4 & -0.7 & 1.7 \\
$\mathbf{- 1 0 / - 5}$ & 20 & 20 & 17 & -0.3 & -2.6 & -2.9 \\
$\mathbf{- 5 / - 2}$ & 29 & 32 & 39 & 3.4 & 6.5 & 9.9 \\
$\mathbf{- 2 / - 1 . 5}$ & 10 & 18 & 54 & 7.3 & 35.7 & 43.0 \\
$\mathbf{- 1 . 5 / - 1 . 2 5}$ & 10 & 21 & 38 & 11.5 & 16.9 & 28.4 \\
$\mathbf{- 1 . 2 5 / - 1}$ & 20 & 52 & 55 & 32.2 & 3.4 & 35.6 \\
$\mathbf{- 1 / - 0 . 7 5}$ & 48 & 82 & 59 & 34.5 & -23.2 & 11.2 \\
$\mathbf{- 0 . 7 5 / - 0 . 5}$ & 84 & 67 & 49 & -16.6 & -18.5 & -35.0 \\
$\mathbf{- 0 . 5 / - 0 . 2 5}$ & 77 & 45 & 37 & -31.7 & -7.5 & -39.2 \\
$\mathbf{- 0 . 2 5 / 0}$ & 39 & 23 & 19 & -15.9 & -3.8 & -19.8 \\
$>\mathbf{0}$ & 68 & 39 & 32 & -28.8 & -6.5 & -35.3 \\
\hline Total & $\mathbf{4 0 9}$ & $\mathbf{4 0 9}$ & $\mathbf{4 0 8}$ & $\mathbf{- 0 . 9}$ & $\mathbf{- 0 . 2}$ & $\mathbf{- 1 . 1}$ \\
\hline
\end{tabular}

Tab. 2b

\begin{tabular}{|c|c|c|c|c|c|c|c|c|c|c|c|c|}
\hline \multirow{2}{*}{$\begin{array}{l}\text { Depth } \\
\text { interval } \\
(\mathrm{m})\end{array}$} & \multicolumn{4}{|c|}{1927 Area $\left(\mathrm{km}^{2}\right)$} & \multicolumn{4}{|c|}{1970 Area $\left(\mathrm{km}^{2}\right)$} & \multicolumn{4}{|c|}{2002 Area $\left(\mathrm{km}^{2}\right)$} \\
\hline & A & B & C & D & A & B & C & D & $\mathbf{A}$ & B & C & D \\
\hline$<25$ & 0 & 0 & 0 & 0 & 0 & 0 & 0 & 0 & 0 & 0 & 0 & 0 \\
\hline$-25 /-20$ & 0 & 0 & 0 & 0 & 0 & 0 & 0 & 0 & 0 & 0 & 0 & 0 \\
\hline$-20 /-15$ & 0 & 0 & 0 & 0 & 0 & 0 & 1 & 0 & 0 & 0 & 1 & 0 \\
\hline$-15 /-10$ & 0 & 3 & 2 & 0 & 0 & 4 & 2 & 0 & 0 & 4 & 2 & 0 \\
\hline$-10 /-5$ & 4 & 6 & 6 & 3 & 4 & 6 & 6 & 4 & 4 & 5 & 5 & 4 \\
\hline$-5 /-2$ & 5 & 7 & 8 & 8 & 5 & 6 & 9 & 11 & 5 & 7 & 14 & 12 \\
\hline$-2 /-1.5$ & 1 & 1 & 4 & 4 & 1 & 3 & 8 & 6 & 1 & 6 & 34 & 12 \\
\hline$-1.5 /-1.25$ & 0 & 2 & 4 & 3 & 1 & 5 & 10 & 6 & 1 & 11 & 15 & 12 \\
\hline$-1.25 /-1$ & 1 & 4 & 7 & 8 & 5 & 14 & 17 & 16 & 9 & 20 & 11 & 15 \\
\hline$-1 /-0.75$ & 6 & 11 & 14 & 16 & 13 & 25 & 26 & 18 & 15 & 18 & 9 & 18 \\
\hline$-0.75 /-0.5$ & 15 & 24 & 25 & 20 & 20 & 11 & 18 & 18 & 21 & 7 & 8 & 13 \\
\hline$-0.5 /-0.25$ & 19 & 13 & 24 & 21 & 16 & 8 & 7 & 14 & 15 & 4 & 8 & 10 \\
\hline$-0.25 / 0$ & 16 & 8 & 8 & 8 & 9 & 2 & 5 & 7 & 7 & 3 & 5 & 4 \\
\hline$>0$ & 21 & 8 & 19 & 19 & 12 & 3 & 12 & 11 & 10 & 3 & 8 & 10 \\
\hline Total & 88 & 88 & 121 & 111 & 88 & 87 & 121 & 111 & 88 & 87 & 121 & 111 \\
\hline
\end{tabular}

Tab. 2c

\begin{tabular}{|c|c|c|c|c|c|c|c|c|c|c|c|c|}
\hline \multirow{2}{*}{$\begin{array}{c}\text { Depth } \\
\text { interval } \\
(\mathrm{m})\end{array}$} & \multicolumn{4}{|c|}{$\begin{array}{c}\text { Area changes 1970-1927 } \\
\left(\mathrm{km}^{2}\right)\end{array}$} & \multicolumn{4}{|c|}{$\begin{array}{c}\text { Area changes 2002-1970 } \\
\left(\mathrm{km}^{2}\right)\end{array}$} & \multicolumn{4}{|c|}{$\begin{array}{c}\text { Area changes 2002-1927 } \\
\left(\mathrm{km}^{2}\right)\end{array}$} \\
\hline & A & B & $\mathrm{C}$ & D & A & B & c & D & A & B & C & D \\
\hline$<25$ & 0.0 & 0.0 & 0.0 & 0.0 & 0.0 & 0.0 & 0.0 & 0.0 & 0.0 & 0.0 & 0.0 & 0.0 \\
\hline$-25 /-20$ & 0. & 0.0 & 0.0 & 0.0 & 0 & 0.0 & 0.1 & & .0 & 0.0 & 0.1 & 0.0 \\
\hline$-20 /-$ & 0 & 01 & 1.0 & 0. & & 0. & 0.0 & & 0.0 & 0. & 0.9 & 0.0 \\
\hline & & & & & & & & & & & & 0.2 \\
\hline$-10 /-$ & -0.2 & 0 & -0.7 & 0.4 & -0.5 & -0.5 & -1.1 & -0.4 & -0.7 & -0.5 & -1.7 & 0.1 \\
\hline$-5 /-2$ & & -1.2 & 0.9 & 3.1 & -0.3 & 0.6 & 5.2 & & 0.2 & -0.6 & 6.1 & 4.2 \\
\hline-2 & & & & & & & 26.7 & & & & 30.3 & 8.0 \\
\hline$-1.5 /-1.25$ & 0 & 2. & 5.4 & 3. & -0.1 & 5. & 5.4 & 5 & 0.4 & 8. & 10.8 & 8.6 \\
\hline$-1.25 /-1$ & 4.2 & 10.3 & 9.7 & 7.9 & 3.6 & 6.5 & -5.5 & -1.2 & 7.8 & 16.8 & 4.2 & 6.7 \\
\hline$-1 /-0.75$ & 6.5 & 14.1 & 12.2 & 1.7 & 2.2 & -7.8 & -17.7 & 0.0 & 8.7 & 6.3 & -5.4 & 1.6 \\
\hline$-0.75 /-0.5$ & & -12 & & -2 & 0.2 & -4 & -10.2 & -4.2 & 5.9 & -17.2 & -16.8 & -7.0 \\
\hline-0.5 & -2.8 & -5 . & -16.5 & -6.8 & -0.8 & -4.1 & 0.9 & -3.6 & -3.6 & -9.6 & -15.6 & -10.4 \\
\hline$-0.25 / 0$ & -6.4 & -5.5 & -3.0 & -1.0 & -2.1 & 0.5 & 0.5 & -2.6 & -8.6 & -5.0 & -2.5 & -3.6 \\
\hline$>0$ & -8.9 & -5.0 & -7.2 & -7.6 & -2.0 & 0.2 & -3.7 & -1.0 & -10.9 & -4.7 & -10.9 & -8.6 \\
\hline
\end{tabular}



Tab. 3

\begin{tabular}{|c|c|c|c|c|c|c|}
\hline \multirow[t]{2}{*}{ Entire Lagoon of Venice } & \multicolumn{3}{|c|}{$1927-70$} & \multicolumn{3}{|c|}{$1970-2002$} \\
\hline & $\mathrm{Km}^{2}$ & $\begin{array}{c}\text { Depth } \\
\text { variation }(m)\end{array}$ & $\mathrm{Mm}^{3}$ & $\mathrm{~km}^{2}$ & $\begin{array}{c}\text { Depth } \\
\text { variation }(m)\end{array}$ & $\mathrm{Mm}^{3}$ \\
\hline \multicolumn{7}{|l|}{ sedimentation inside lagoon } \\
\hline a) within channels & 44 & 0.05 & 2 & 50 & 0.40 & 20 \\
\hline B completely filled channels & 7 & 2.08 & 15 & 14 & 0.87 & 12 \\
\hline c) extension of saltmarshes & 4 & 1.08 & 4 & 4 & 0.62 & 3 \\
\hline dredged sediments & 22 & -2.78 & -60 & 9 & -1.22 & -11 \\
\hline \multicolumn{7}{|l|}{ sediment eroded } \\
\hline a) tidal and subtidal flats & 269 & -0.07 & -18 & 287 & -0.19 & -54 \\
\hline b) saltmarshes & 26 & -0.63 & -16 & 10 & -0.67 & -7 \\
\hline $\begin{array}{l}\text { artificial saltmarshes } \\
\text { disposed of outside lagoon }\end{array}$ & & & 60 & 4 & 0.91 & $\begin{array}{l}3 \\
8\end{array}$ \\
\hline lost through inlets & & & -13 & & & -26 \\
\hline
\end{tabular}


Tab. 4

\begin{tabular}{|c|c|c|c|c|c|c|c|}
\hline & Sub-basin & $\begin{array}{l}\text { Budget } \\
\left(\mathrm{Mm}^{3}\right)\end{array}$ & $\begin{array}{c}\text { Disposal } \\
\text { outside } \\
\left(\mathrm{Mm}^{3}\right)\end{array}$ & $\begin{array}{l}\text { Lost to sea } \\
\left(\mathrm{Mm}^{3}\right)\end{array}$ & $\begin{array}{c}\text { Rate of } \\
\text { loss in } \\
\mathrm{m}^{3^{*}} 10^{3} \mathrm{yr}^{-1}\end{array}$ & $\begin{array}{c}\text { Rate of } \\
\text { loss in } \\
\text { tons }{ }^{\wedge} 10^{3} \\
\mathrm{yr}^{-1}\end{array}$ & $\begin{array}{c}\text { River } \\
\text { input } \\
\mathrm{m}^{3} 10^{3} \mathrm{yr}^{-1}\end{array}$ \\
\hline 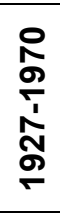 & $\begin{array}{l}\text { A - Treporti } \\
\text { B - Lido } \\
\text { C - Malamocco } \\
\text { D - Chioggia } \\
\text { Total Lagoon }\end{array}$ & $\begin{array}{c}-7,0 \\
-20,0 \\
-34,2 \\
-12,0 \\
-73,2 \\
\end{array}$ & $\begin{array}{c}6 \\
17 \\
30 \\
7 \\
60 \\
\end{array}$ & $\begin{array}{l}-1,0 \\
-3,0 \\
-4,2 \\
-5,0 \\
-13,2 \\
\end{array}$ & $\begin{array}{l}-23 \\
-70 \\
-98 \\
-116 \\
-307 \\
\end{array}$ & $\begin{array}{l}-31 \\
-92 \\
-130 \\
-153 \\
-406 \\
\end{array}$ & \\
\hline 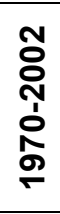 & $\begin{array}{l}\text { A - Treporti } \\
\text { B - Lido } \\
\text { C - Malamocco } \\
\text { D - Chioggia } \\
\text { Total Lagoon }\end{array}$ & $\begin{array}{c}1,7 \\
-4,1 \\
-24,1 \\
-8,0 \\
-34,4\end{array}$ & $\begin{array}{l}0 \\
2 \\
3 \\
3 \\
8\end{array}$ & $\begin{array}{c}1,7 \\
-2,1 \\
-21,1 \\
-5,0 \\
-26,4 \\
\end{array}$ & $\begin{array}{c}54 \\
-65 \\
-659 \\
-156 \\
-826 \\
\end{array}$ & $\begin{array}{c}71 \\
-85 \\
-870 \\
-206 \\
-1090\end{array}$ & $\begin{array}{c}14 \\
8 \\
4 \\
7 \\
33 \\
\end{array}$ \\
\hline
\end{tabular}

$(\wedge)$ Volume estimates assume uniform density of $2,650 \mathrm{kgm}^{-3}$ and $50 \%$ porosity 
Tab. 5

\begin{tabular}{ccccccc}
\hline $\begin{array}{c}\text { Sub- } \\
\text { basins }\end{array}$ & $\begin{array}{c}\text { Sand 1970 } \\
(\%)\end{array}$ & $\begin{array}{c}\text { Sand 2000 } \\
(\%)\end{array}$ & $\begin{array}{c}\text { Silt 1970 } \\
(\%)\end{array}$ & $\begin{array}{c}\text { Silt 2000 } \\
(\%)\end{array}$ & $\begin{array}{c}\text { Clay 1970 } \\
(\%)\end{array}$ & $\begin{array}{c}\text { Clay 2000 } \\
(\%)\end{array}$ \\
\hline A & $8(0-49)$ & $11(2-43)$ & $68(44-84)$ & $61(45-72)$ & $24(8-51)$ & $29(11-43)$ \\
B & $19(3-64)$ & $31(1-91)$ & $60(25-86)$ & $48(6-70)$ & $21(8-35)$ & $22(3-46)$ \\
C & $40(3-96)$ & $42(6-83)$ & $41(2-65)$ & $41(12-73)$ & $19(1-45)$ & $18(3-40)$ \\
D & $39(0-97)$ & $48(1-98)$ & $42(2-73)$ & $36(1-62)$ & $20(1-47)$ & $16(0-45)$ \\
\hline
\end{tabular}




\begin{tabular}{ccccccc}
\hline $\begin{array}{c}\text { Sub- } \\
\text { zone }\end{array}$ & Area ID & $\begin{array}{l}\text { Erosion/ } \\
\text { Deposition } \\
\text { regime }\end{array}$ & $\mathrm{km}^{2}$ & $\begin{array}{c}\text { Mean } \\
\text { depth } \\
\text { variation } \\
(\mathrm{m})\end{array}$ & $\begin{array}{c}\text { Sedimentation/erosion } \\
\text { rate }\left(\mathrm{cm} \mathrm{yr} \mathrm{r}^{-1}\right)\end{array}$ & $\begin{array}{c}\text { Volume } \\
\left(\mathrm{Mm}^{3}\right)\end{array}$ \\
\hline I & A & SD & 19 & 0.12 & 0.4 & 2 \\
II & A/B & SD & 28 & 0.08 & 0.3 & 2 \\
III & B & ME & 24 & -0.23 & -0.7 & -5 \\
IV & C & SE & 27 & -0.81 & -2.5 & -22 \\
V & C/D & SD & 16 & 0.11 & 0.4 & 2 \\
VI & D & SE & 8 & -0.60 & -1.9 & -5 \\
\hline
\end{tabular}

SD: stability + deposition; ME: moderate erosion; SE: strong erosion 